\title{
Regional Modeling of Climate Change Impacts on Groundwater Resources Sustainability in Peninsular Malaysia
}

\author{
K. A. Mogaji ${ }^{1}$ H. S. $\operatorname{Lim}^{1} \&$ K. Abdullah ${ }^{1}$ \\ ${ }^{1}$ School of Physics, Universiti Sains Malaysia, Penang, Malaysia \\ Correspondence: K. A. Mogaji, School of Physics, Universiti Sains Malaysia, Penang 11800, Malaysia. Tel: \\ 60-16-830-151. E-mail: mka11_phy037@student.usm.my
}

Received: January 21, 2013

Accepted: March 21, 2013 Online Published: April 25, 2013

doi:10.5539/mas.v7n5p72

URL: http://dx.doi.org/10.5539/mas.v7n5p72

\begin{abstract}
Projection of climate for the 2020s and 2080s from an ensemble of global climate models (GCMs) run under A2, $\mathrm{A} 1 \mathrm{~B}$ and $\mathrm{B} 1$ emission scenarios are used for regional modeling of climate change impacts on groundwater resources sustainability in Peninsular Malaysia. Few studies that have modeled climate change impacts on groundwater resources used the physically-based surface-subsurface flow model. In this paper, the suite of GCM outputs were modeled for the impact studies via integrative approach involving empirical modeling equation, GIS-based geostatistical technique and model forecasting accuracy optimization. A range of predictions is obtained by modeling the precipitation and temperature change factors derived from fifteen (15) GCMs forced with three (3) future emission scenarios for 50 years periods between 2000 to 2049 (2020s) and 2050 to 2099 (2080s) reference to the baseline period (1950 to 1999). The ensemble average suggests there will be a $1 \%$ reduction in monthly recharge in 2020 s and $7-10 \%$ recharge increment in 2080 s across the study area. The spread of predictions for recharge and PET rates across the area ranges from 12.05 to $17.83 \mathrm{~mm} /$ day and 3.72 to 4.05 , respectively. Geostatistical analysis enabled generation of recharge rate and PET rate prediction maps. The prediction maps were classified into low (L), medium (M) and high $(\mathrm{H})$ recharge and PET rated zones in GIS environment. The recharge rate model map revealed that more than $60 \%$ of the area coverage in the study area is characterized by low rating recharge, particularly within 2020 s future period. The multiple climate models results provided the highest likelihood mean estimate as well as a measure of its uncertainty and less probable outcomes. Results suggest that recharge reduction in the area is an evidence of water resources scarcity in 2020s. The results of this work provided the basis for the inclusion of representative climate scenarios into the Peninsular Malaysia water resources' existing decision support system model useful for policy and decision making in the area.
\end{abstract}

Keywords: groundwater resources, global climate model, geostatistical-technique, PET rate, emission-scenario and climate change

\section{Introduction}

Estimating the possible impacts of climate change on water resources represents one of the most difficult challenges faced by water resources managers. Because water is an invaluable natural resources, various studies has indeed shown great interest in such projections, through published articles (Christensen et al., 2004 ; Fowler et al., 2003; Fowler et al., 2007; Van-Rheenen et al., 2004). This unprecedented well-evidenced global warming and its associated impacts on human society have indeed drawn considerable concerns from academic circles, public and governments. According to Bates et al. (2008), the global climate change will adversely impacted the water resources in many regions in the world. As such, prompt remediation measures and appropriate management strategies need to be implemented to curtail the negative influences of this phenomenon.

The effects of global warming on the environment are enormous. These include; alterations of the global hydrological cycle, increase of the global continental runoff (Mc Carthy et al., 2001; Labat et al., 2004). The IPCC reports on the global climate warming impact in the last century are unequivocal (IPCC, 2007). The cause of global warming was actually initiated by the anthropogenic release of carbon dioxide resulting from the massive industrialization and the extended use of fossil fuels (Labat et al., 2004). The gaseous emission resulted to geometrical atmospheric concentrations of greenhouse gases (GHG) in the world atmosphere. The climate variables such as temperature and precipitation suffers anomalous changes because of the instability of the global 
atmospheric dynamism (Chen et al., 2006; Xu et al., 2006; Zhang et al., 2008a, b; Gao et al., 2008). The adverse of global warming impact was largely felt on the volume of water that comprises aquifer recharge either increasing or decreasing it (Eckhardt \& Ulbrich., 2003; Scibek \& Allen, 2006). In accordance with Scibek et al. (2007), the changes in surface water levels that often occurs during dry spell is inimical to aquifers effectiveness and can reduced groundwater level. In a recent literature by Goderniaux et al. (2009), emphasis on a reliable estimate of the volume of water entering and leaving an aquifer is a requirement for estimating impact of climate change on groundwater system. As such, the prediction and estimation of groundwater recharge that represents the connection between atmospheric and surface-subsurface processes is therefore a key element in the context of modeling impact of climate change on groundwater resources.

Several researchers had extensively investigated the impact of climate change on water resources with useful contributions to the schemes of water resources management (Mimikou et al., 2000; Piao et al., 2010; Akhtar et al., 2008; Mauser \& Bach, 2009; Kay et al., 2006). However, most of these studies focused on surface water resources and generally neglect groundwater (Goderniaux et al., 2009). According to IPCC, 2008 report, several gaps in knowledge related to climate change and water resources had been identified. The report emphasized on the need to improve the understanding of climate change and its variability effects on groundwater. Meanwhile, the limited findings from the available climate change impact studies related to groundwater had established the expected potential consequences of climate change on groundwater resources including; the variations in groundwater level fluctuation, effects on soil pore water pressure alteration of groundwater flow regimes, and changes in the volume and quality of groundwater (Brouyere et al., 2004; Bloomfield et al., 2006; Ranjan et al., 2006; Chen et al., 2004; Collison et al., 2000).

In Peninsular Malaysia, the effects of climate change impact are enormous. The most prominent consequence is the ever-increasing water pollution crisis (Perry \& Landsberg, 1977). Studies to prevent the vulnerability of groundwater resources which constitute the largest sources of fresh water worldwide (Todds \& Mays, 2005) are utmost importance to water resources manager. Therefore, assessing climate change impact on groundwater resources with the view of maintaining long term sustainability of the resources under projected extreme weather condition in the country is the quest of this study. Though, the current water resources management systems are relatively effective in handling the inter-annual variability. However, not enough consideration has been given to long term trends climate change modeling. In lieu of this, the authors find it justifiable that an assessment of the long term impacts of climate change on water resources is essential to plan for future management strategies.

Presently, within the scope of literatures, research on the impact of climate change on water resources sustainability in the Southeast Asia is largely limited. Considering the limited number of groundwater related studies, particularly within Peninsular Malaysia, and the available work carried out by Shaaban et al. (2011) assessing the regional modeling of climate change impact on water resources, this paper presented a methodology to model the anticipated climate change impacts on the groundwater resources in Peninsular Malaysia using outputs from fifteen (15) global climate models (GCM) and their corresponding IPCC A1B, A2 and B1 emissions scenarios. The methodology has been applied to the regional transboundary system of the area with the aim of including the impacts of representative climate scenarios into the Decision Support System (DSS) developed for policy and decision making in the country. This will allow the water resources managers in the country to evaluate the strategies to cope with a changing water balance under future climate change impact.

\section{Description of the Study Area}

\subsection{The Geographic and Human Setting}

The study area is the part of Malaysia located in Malay Peninsula. The area is bounded by latitudes $1^{\circ} 0^{\prime} 0^{\prime \prime} \mathrm{N}-7^{\circ} 0^{\prime} 0^{\prime \prime} \mathrm{N}$ latitude and longitudes $100^{\circ} 0^{\prime} 00^{\prime \prime} \mathrm{E}-104^{\circ} 0^{\prime} 0^{\prime \prime} \mathrm{E}$. The area coverage is approximately 131,598 $\mathrm{km}^{2}$. This region share a land border with Thailand in the north, the Strait of Malaka in the south and South China Sea in the east (Figure 1). The elevation ranges in the area varies between 0 and $8000 \mathrm{~m}$ (Shaaban et al., 2011). The area is peculiarly characterized by highlands, floodplains, and coastal zones. The Sg. Muda, Sg. Pinang, Sg. Perak, and Sg. Klang are some of the rivers that are existing in the area. There is existence of open water bodies, natural wetlands, and manmade lakes such as dams, and ex-mining pools which are mostly found in the Klang and Kinta Basins of the study area. The water bodies are used for power generation, flood control, national water supply, recreation, aquaculture and tourism.

\section{Methodology}

The methodology followed was divided into three parts: (1) Trend projection of the regional precipitation and temperature change estimates for the study periods; (2) Deriving the recharge rate and PET rate estimates for the 
study area and (3) Carry out the global climate models (GCMs) forecasting accuracy evaluation for regional spatial recharge rate and potential evapotranspiration (PET) rate prediction in the area.

\subsection{Regional Climate Change Estimates}

Data from 15 global climate models (GCMs) run under different greenhouse gas induced climate change scenarios were used to derive estimates of precipitation and temperature changes at $0.5^{\circ}$ grid spatial resolution for the periods between 2000 and 2099 (Wood et al., 2004) (Table 1). The global climate models (GCMs) data were obtained from www.engr.scu.edu/ emaurer/global_data/. According to Maurer et al. (2009), the GCMs data were downscaled to $0.5^{\circ}$ grid spatial resolution using the bias-correction/spatial downscaling method based on the 1950-1999 gridded observations of Adam and Lettenmaier (2003). In this study, a total of three (3) emission scenarios-A1B, A2 and B1 representing the average projections of alternative future development, served as the basis for the assessment of future climate change in the area. The chosen scenarios belong to the four different storylines, or scenario families (Table 2).

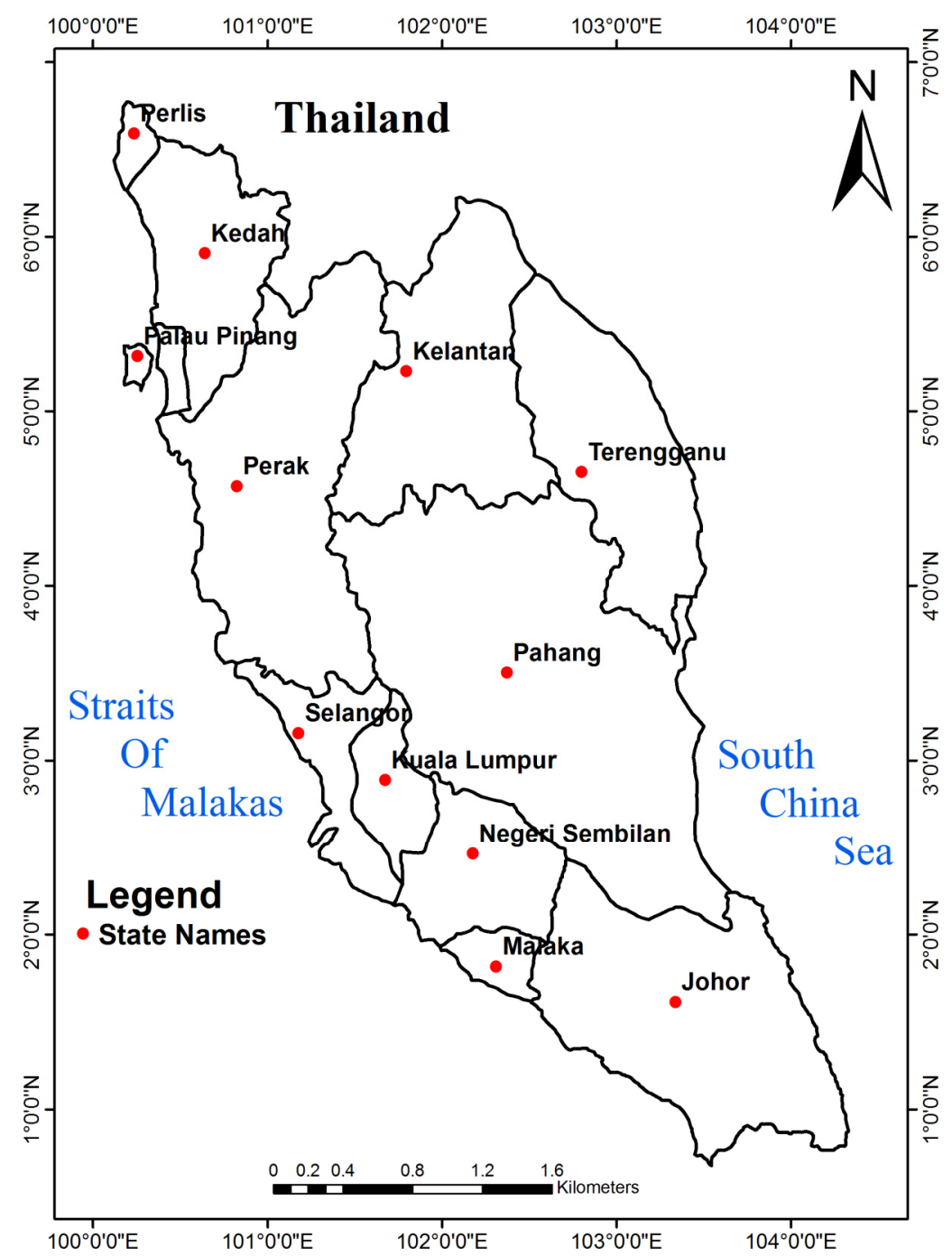

Figure 1. Regional map of the study area showing the states 
Table 1. Global climate models used to produce scenarios assessed in this study

\begin{tabular}{|c|c|c|c|c|}
\hline No. & IPCC Model. I. D. & Modeling Group & Country & Primary References \\
\hline 1 & BCCR-BCM2.0 & $\begin{array}{l}\text { Bjerknes Centre for Climate } \\
\text { Research }\end{array}$ & & (Furevik et al., 2003) \\
\hline 2 & CGCM3.1 (T4.7) & $\begin{array}{c}\text { Canadian Centre for Climate } \\
\text { Modeling and Analysis }\end{array}$ & & (Flato \& Boer, 2001) \\
\hline 3 & CNRM-CM3 & $\begin{array}{l}\text { M'et'eo-France/Centre National de } \\
\text { Recherches M'et'eorologiques }\end{array}$ & France & $\begin{array}{l}\text { (Salas-M'elia et al., } \\
\text { 2005) }\end{array}$ \\
\hline 4 & CSIRO-MK3.0 & CSIRO Atmospheric Research & Australia & (Gordon et al., 2002) \\
\hline 5 & GFDL-CM2.0 & $\begin{array}{c}\text { US Dept. of } \\
\text { Commerce/NOAA/Geophysical } \\
\text { Fluid Dynamics Laboratory }\end{array}$ & USA & (Delworth et al., 2006) \\
\hline 6 & GFDL-CM2.1 & $\begin{array}{c}\text { US Dept. of } \\
\text { Commerce/NOAA/Geophysical } \\
\text { Fluid Dynamics Laboratory }\end{array}$ & USA & (Delworth et al., 2006) \\
\hline 7 & GISS-ER & $\begin{array}{c}\text { NASA/Goddard Institute for Space } \\
\text { Studies, }\end{array}$ & USA & (Russell et al., 2000) \\
\hline 8 & INM-CM3.0 & Institute for Numerical Mathematics & Russia & $\begin{array}{l}\text { (Diansky \& Volodin, } \\
\text { 2002) }\end{array}$ \\
\hline 9 & IPSL-CM4 & Institut Pierre Simon Laplace & France & (IPSL, 2005) \\
\hline 10 & $\begin{array}{l}\text { MIROC3.2 } \\
\text { (medres) }\end{array}$ & $\begin{array}{c}\text { Center for Climate System Research } \\
\text { (The University of Tokyo), NIES \& } \\
\text { JAMSTEC }\end{array}$ & Japan & $\begin{array}{c}\text { (K-1 model developers, } \\
\text { 2004) }\end{array}$ \\
\hline \multirow[t]{2}{*}{11} & ECHO-G & $\begin{array}{l}\text { Meteorological Institute of the } \\
\text { University of Bonn, Meteorological }\end{array}$ & Germany & (Legutke \& Voss, 1999) \\
\hline & & Research Institute of KMA & & \\
\hline 12 & ECHAM5/MPI-OM & $\begin{array}{l}\text { Max Planck Institute for } \\
\text { Meteorology }\end{array}$ & Germany & (Jungclaus et al., 2006) \\
\hline 13 & PCM & $\begin{array}{c}\text { National Center for Atmospheric } \\
\text { Research. }\end{array}$ & USA & (Washington et al., 2000) \\
\hline 14 & CCSM3 & $\begin{array}{l}\text { National Center for Atmospheric } \\
\text { Research }\end{array}$ & USA & (Collins et al., 2006) \\
\hline 15 & UKMO-HadCM3 & $\begin{array}{l}\text { Hadley Centre for Climate Prediction } \\
\text { and Research/Met Office }\end{array}$ & UK & (Gordon et al., 2000) \\
\hline
\end{tabular}

Table 2. The emission scenarios of the IPCC special report on emission scenarios (SRES)

\begin{tabular}{cl}
\hline Scenario & \multicolumn{1}{c}{ Description } \\
\hline & $\begin{array}{l}\text { Described a future world of very rapid economic growth, global population that peaks in } \\
\text { mid-century and decline thereafter, and introduction of new and more efficient } \\
\text { technologies. }\end{array}$ \\
The A1 scenario family develops into three groups that describe alternative directions of \\
technological change in the energy system. The three A1 groups are distinguished by \\
their technological emphasis fossil intensive (A1F1), non-fossil energy sources (A1T), or \\
a balance across all sources (A1B; where balance is defined as not relying too heavily on \\
one particular energy source (a mix of fossil and non-fossil fuel)). \\
Described a very heterogeneous world with continuously increasing global population \\
and regionally oriented economic growth that is more fragmented and slower than in \\
other storylines
\end{tabular}


Described a convergent world with the same global population as the AI story line but

B1 with rapid changes in economics structures toward a service and information economy, with reduction in material intensity, and the introduction of clean and resource-efficient technologies

Describes a world in which the emphasis is local solutions to solution to economic, social, and environmental sustainability, with continuously increasing population (lower than A2) and intermediate economic development. The scenario is oriented towards environmental protection but it focuses on local and regional levels

The 15 GCMs models forced with three greenhouse gas (GHG) emission scenarios were used to evaluate the differences in the projections of precipitation and temperature among the various GCMs (see Table 1). The temperature and precipitation change factors between the periods of 2000-2049 (called 2020s hereafter) and 2050-2099 (called 2080s hereafter) relative to the past 50-year observed period (1950-1999) were evaluated in the current work. The authors purposefully included all of the models in the study to provide a representative uncertainty envelope of the results.

Reliability Ensemble Average (REA) estimates was performed on the GCMs models to evaluate their simulation performance. Figure 2 shows the models that most reliably simulate precipitations variable in the area. Relatively, (4) four GCMs models namely; Miroc 3.2 (medres), UKMO-HadCM3, Echam5/MPI-OM and GISS-ER show the best simulating performance.

\subsection{Recharge and Potential Evapotranspiration (PET) Modeling}

The variation in the potential recharge and the potential evapotranspiration (PET) rate were modeled across the predicted periods (2020s and 2080s) using the empirical relationship model equation and an analytical method of approach, respectively.

The recharge rate modeling was based on the estimated precipitation changes obtained from the downscaled GCMs models. The empirical relationship model equation developed by Anderson et al. (1992) used in Serrat-Cap-devila et al. (2007) was adopted. This is expressed in Equation 1.

$$
\log (\text { Qrech })=-1.4+0.98 * \log (\mathrm{P}-8)
$$

Where $\mathrm{P}$ is the estimated precipitation from the downscaled GCMs output and Qrech is the recharge estimate.

The PET rate series was modeled using the temperature-based Blaney-Criddle equation developed by Blaney and Criddle, 1950 used in Philip and Batelaan (2009). This is expressed in Equation 2.

$$
\mathrm{PET}=\mathrm{Kp}(0.46 \mathrm{Tm}+8.13)
$$

Where Tm is the downscaled temperature from GCMs models, $p$ : the monthly or daily percentage of daytime hours; and $K$ : the monthly consumptive use coefficient, depending on vegetation type, location and season. At the equator, $p=0.27$. The value of $K=0.69$.

\subsection{Model Accuracy Evaluation for Recharge and PET Rates Spatial Prediction}

The evaluation of the GCMs models accuracy for the purpose of regional spatial hydrological prediction in this study was carried out on the $15 \mathrm{GCMs}$ models prediction using the recharge rate estimated output. The mean error (ME) optimization criteria algorithm equation by Anderson and Woessner (1992) cited in van Roosmalen, et al. (2007) was used for the model accuracy evaluation. This is expressed in Equation 3.

$$
M E=\frac{1}{n} \sum_{i=1}^{n}\left(H_{o b s i}-H_{\text {simi }}\right)
$$

Where $n$ is the number of observations, and Hobs, $i$ and Hsim, $i$ are the observed/Ensemble and simulated recharge rate, respectively. The result of the model accuracy evaluation is shown in Table 3. In accordance with Table 3, MIROC 3.2 (medres) was identified the best forecasting model because of its minimum error result. The result of the model performance evaluation and the GCMs models forecasting accuracy analysis are in good agreement (Table 3 and Figure 2).

Considering the best forecasting GCM model (Miroc 3.2 (medres)), point data variables (Temperature and Precipitation) for each state in the study area (Figure 1) were extracted using the script developed program compatible with Ferret software in a Linus 2.6 generic operating system (OS). The obtained point data were analyzed for the two future periods (2020s and 2080s). The analyzed data were used to determine recharge and 
PET rate across all the emission scenarios (A1B, B1 and A2). With the use of GIS software, geostatistical analysis was performed on the analyzed point data (i.e. the determined recharge rate and PET rate) to generate spatial prediction model maps for those periods. The produced recharge rate and PET rate model maps were cross validated via geostatistical analysis to evaluate the prediction accuracy in the area. Table 4 presents the prediction errors obtained in the area. According to Table 4, the mean prediction error is very close to zero (i.e. 0.329), this implies that the predictions are unbiased. Similarly, the Root-Mean-Square Standardized error is close to 1 suggesting that the standard errors are accurate. On the final note, the small Root- Mean-Square error obtained is indicative of the closeness of the predictions to the measured values (Johnston et al., 2003).

Table 3. Forecasting model accuracy results

\begin{tabular}{ccc}
\hline GCMs MODELS & Observed & Ensemble \\
\hline CGCM3.1(T47) & -18.3617 & -0.28156 \\
UKMO-HadCM3 & -20.805 & -2.72489 \\
BCCR-BCM2.0 & -15.7025 & 2.377611 \\
CNRM-CM3 & -10.7533 & 7.326778 \\
CSIRO-Mk3.0 & -18.0725 & 0.007611 \\
MICROC3.2(medres) & -37.725 & -19.6449 \\
IPSL-CM4 & -6.66083 & 11.41928 \\
INM-CM3.0 & -14.3658 & 3.714278 \\
GFDL-CM2.1 & -15.0267 & 3.053444 \\
GFDL-CM2.0 & -15.5117 & 2.568444 \\
GISS-ER & -9.72333 & 8.356778 \\
NCAR-CCSM3 & -23.865 & -5.78489 \\
ECHO-G & -25.3017 & -7.22156 \\
NCAR-PCM & -16.4425 & 1.637611 \\
ECHAM5/MPI-OM & -22.8842 & -4.80406 \\
\hline
\end{tabular}

Table 4. Prediction errors obtained from the geostatistical analysis

\begin{tabular}{cc}
\hline Prediction errors & Value \\
\hline Mean & 0.329 \\
Root-Mean-Square & 1.836 \\
Average standard error & 2.13 \\
Mean standardized & 0.1154 \\
Root-Mean-Square standardized & 0.7644 \\
\hline
\end{tabular}

\section{Results and Discussions}

\subsection{The Trend Projection for the Climate Change Variables}

The analysis of the multiple GCMs models in Figures $3 \mathrm{a}$ and $3 \mathrm{~b}$ show the future projections of the precipitation changes for the future predicted periods (2020s and 2080s). The identified four GCMs models shown to have the best simulation performance in the area have been highlighted in order to see where their projections lie within the range of future estimates. The results show that the best performed models projections enveloped the ensemble average projection indicating their closeness to the ensemble average projection trend but with unparallel match. Such disagreement in future projections between GCMs models that perform best simulating historical records validates the argument of using multiple GCMs models for the purpose of improving climate change prediction. The results quite supported the argument of Weisheimer et al. (2009) and Devineni and Sankarasubramanian (2010). (see similar trend of projections of A1B and B1 Scenarios) [appendix A]. 
Figures 4a, 4b and Figures 5a, 5b show the comparism simulation trend plots for the relative changes in monthly temperature and precipitation for 2020s and 2080s periods coupled with the baseline/reference period projection. Inter-annually, the general variations of the average monthly precipitation and temperature are similar across the predicted periods. However, the range of precipitation and temperature changes within each month for 2080s are much higher than those for 2020s. The rises in the temperature and precipitation magnitude may likely due to greater concentration of $\mathrm{CO}_{2}$ in the distance future relative to GHG emission scenarios. On the other hand, the results shown in Figures $4 \mathrm{a}, 4 \mathrm{~b}$ and Figures 5a, 5b could implies changes in the distribution of river flows and groundwater recharge over space and time which are determined by climate change variables such as temperature, evaporation and, crucially, precipitation (Chiew, 2007).

The analyzed seasonal and annual changes in precipitation and temperature factors for 2080s are also higher than those for 2020s (Figures 6a, 6b and Figures 7a, 7b). In Figures 6a and 6b, a notable anomalously high precipitation identified occurs during the northeast monsoon season while a relative precipitation decreases is observed over the southwest monsoon season in the area. The temperature projection trend (Figures 7a and 7b) shows that the magnitudes of the temperature factor variation are relatively uniform in the study area. However, a remarkable temperature increase is observed during the inter monsoon season across those periods. The quantitative interpretation results of Figures $6 \mathrm{a}, 6 \mathrm{~b}$ and Figures $7 \mathrm{a}, 7 \mathrm{~b}$ are presented in Table 5. Table 5 analysis gives the expected monthly changes in precipitation and temperature factors. The projected precipitation increase estimated could be due to the increase in northeastern monsoon precipitation observed in the area. On the other hand, the monthly projected increase in temperature is noted to be higher during inter monsoon season compare to other seasons
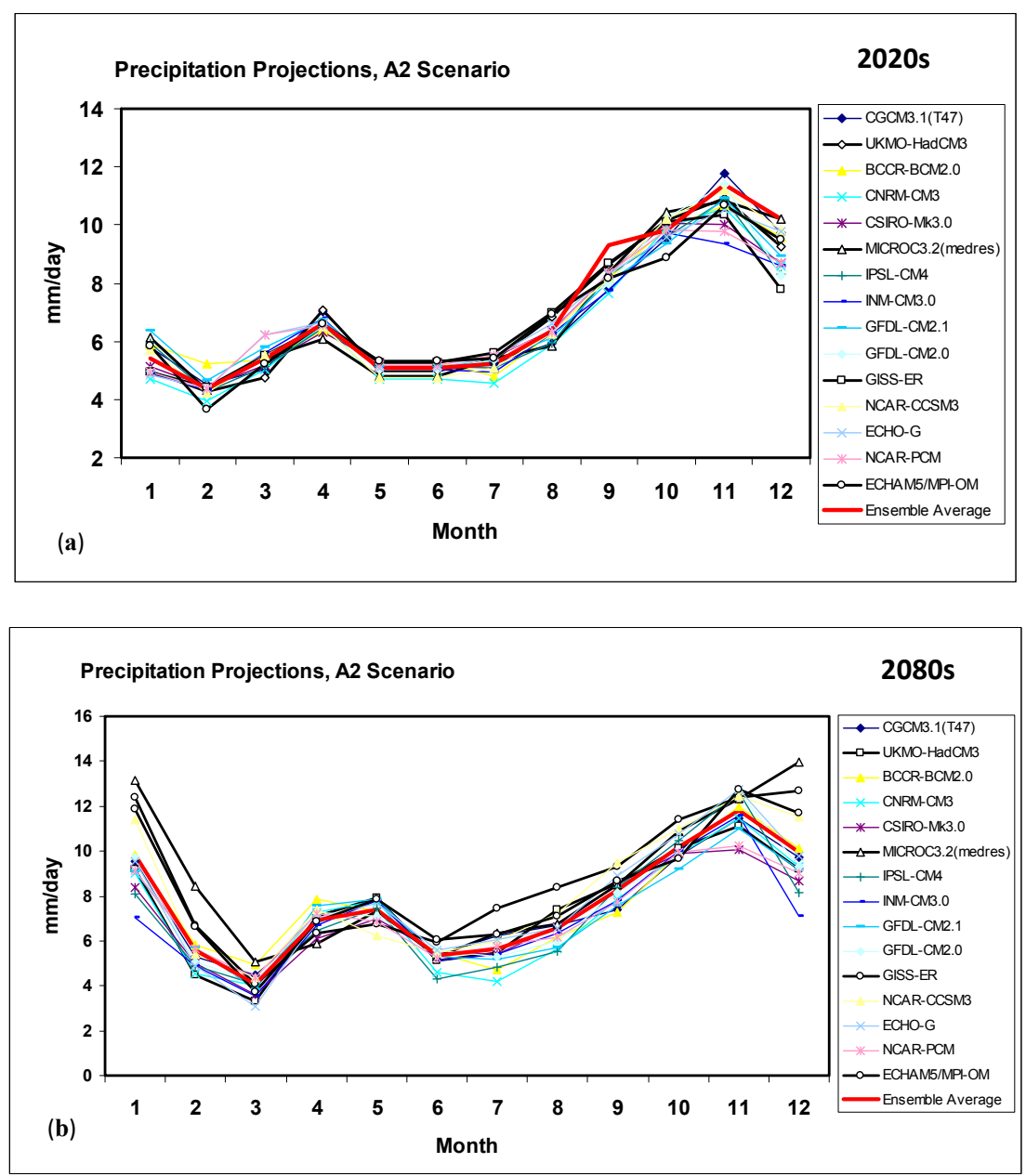

Figure 3. Regional precipitation projection of the 15 GCMs. The four best performing models were highlighted (Echam5-MPI-OM, Miroc3_2 (medres), UKMO-HadCM3, GISS-ER 

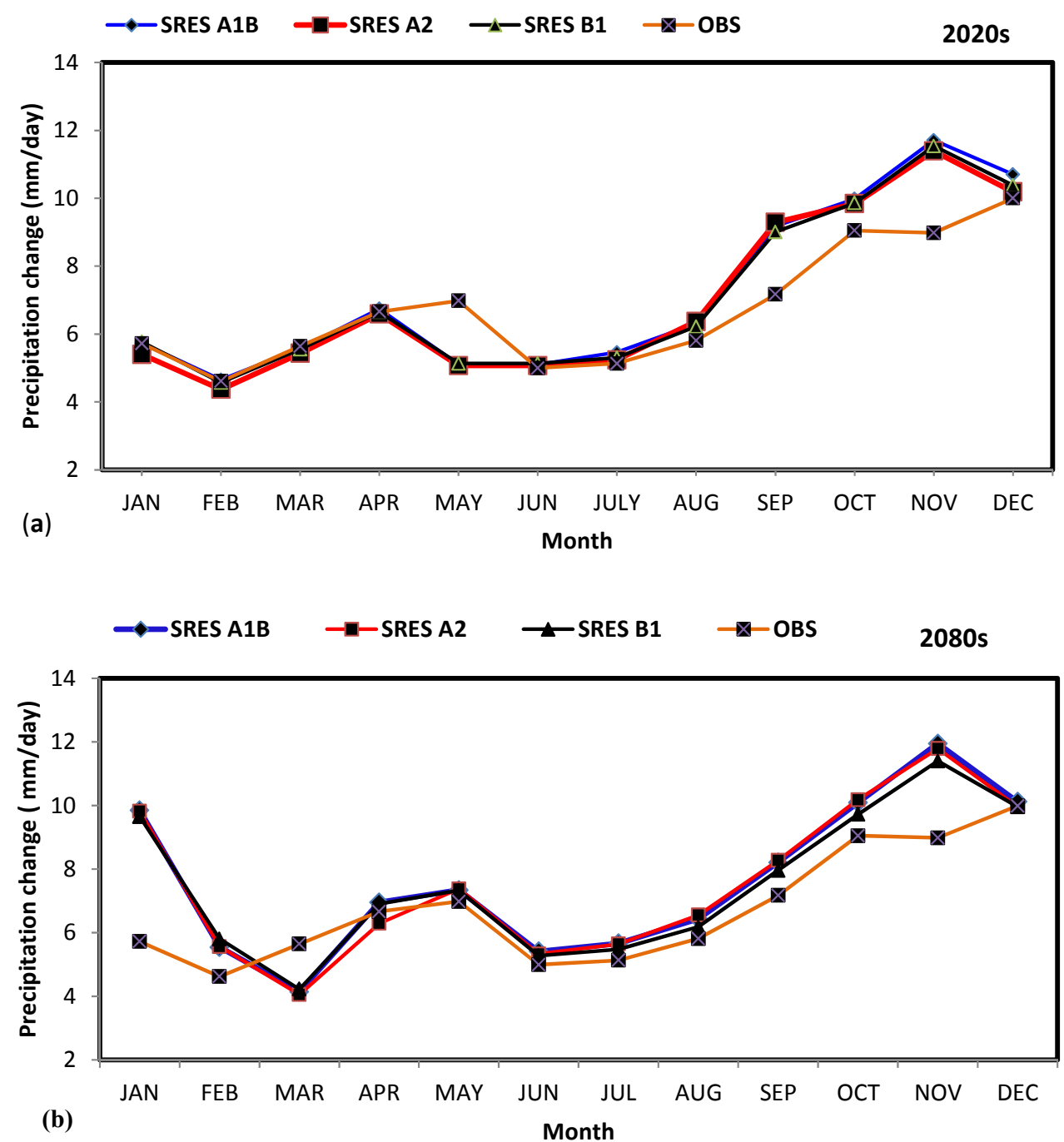

Figure 4. Comparative plots of relative changes in monthly precipitation under 45 scenarios for 2020 s, 2080s and the observed trends

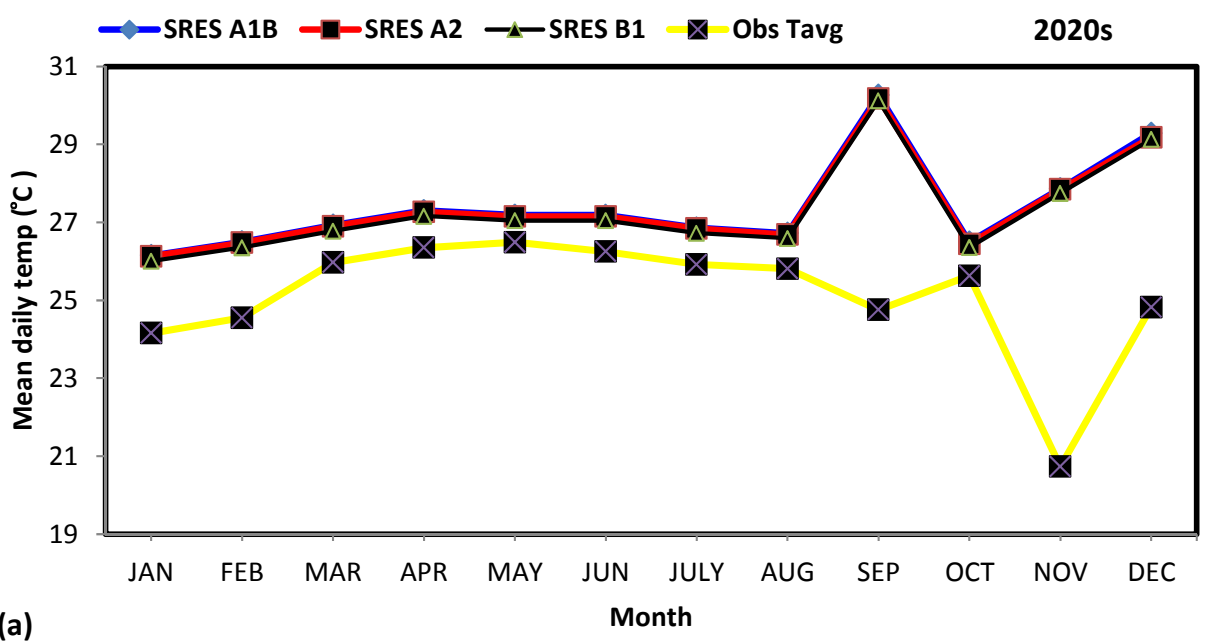




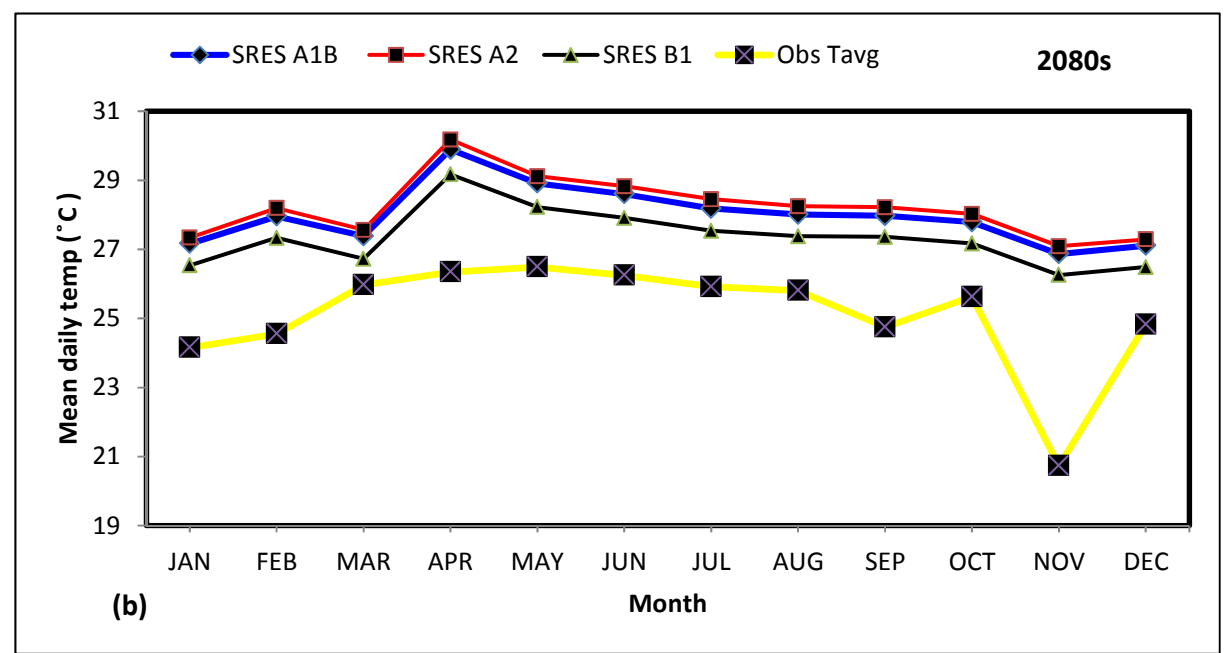

Figure 5. Comparative plots of relative changes in monthly temperature under 45 scenarios for 2020s, 2080s and the observed trends

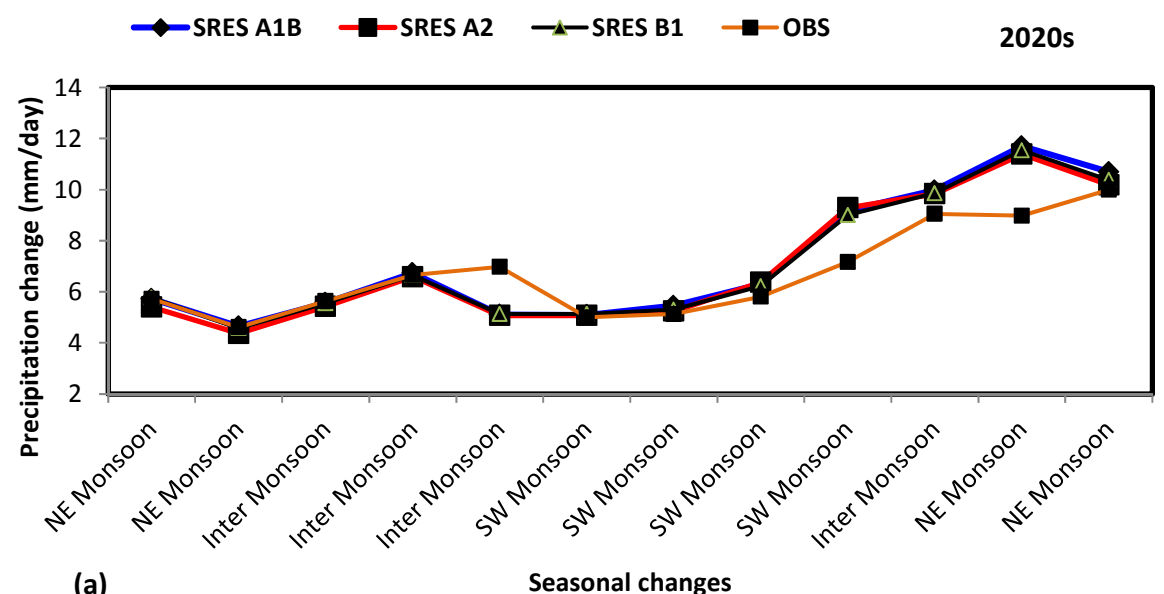

(a)

Seasonal changes

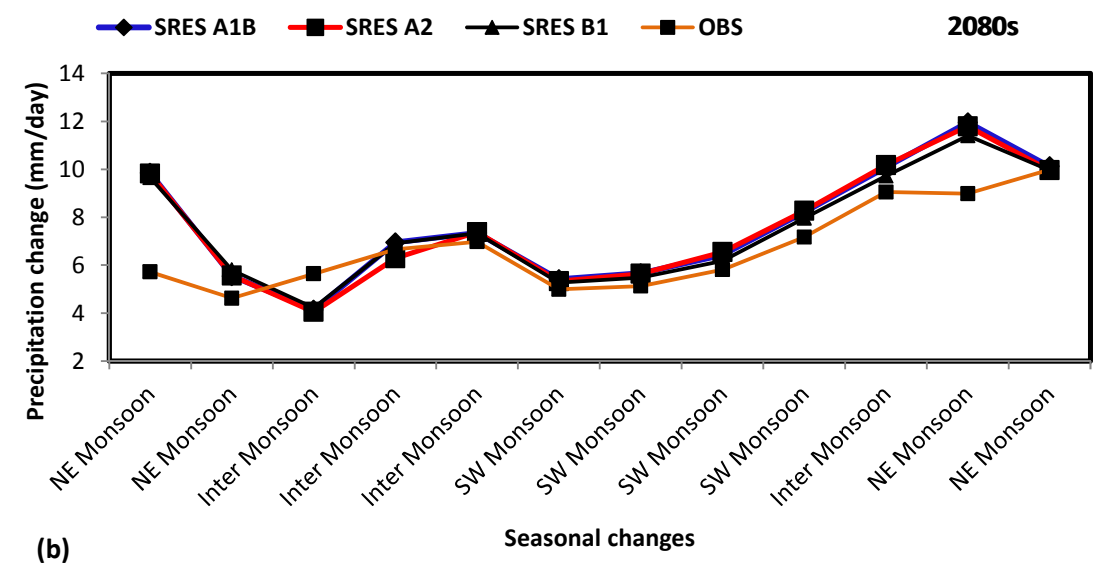

Figure 6. Plots for changes in seasonal and monthly precipitation under 45 scenarios for 2020s, 2080s and the observed trends 

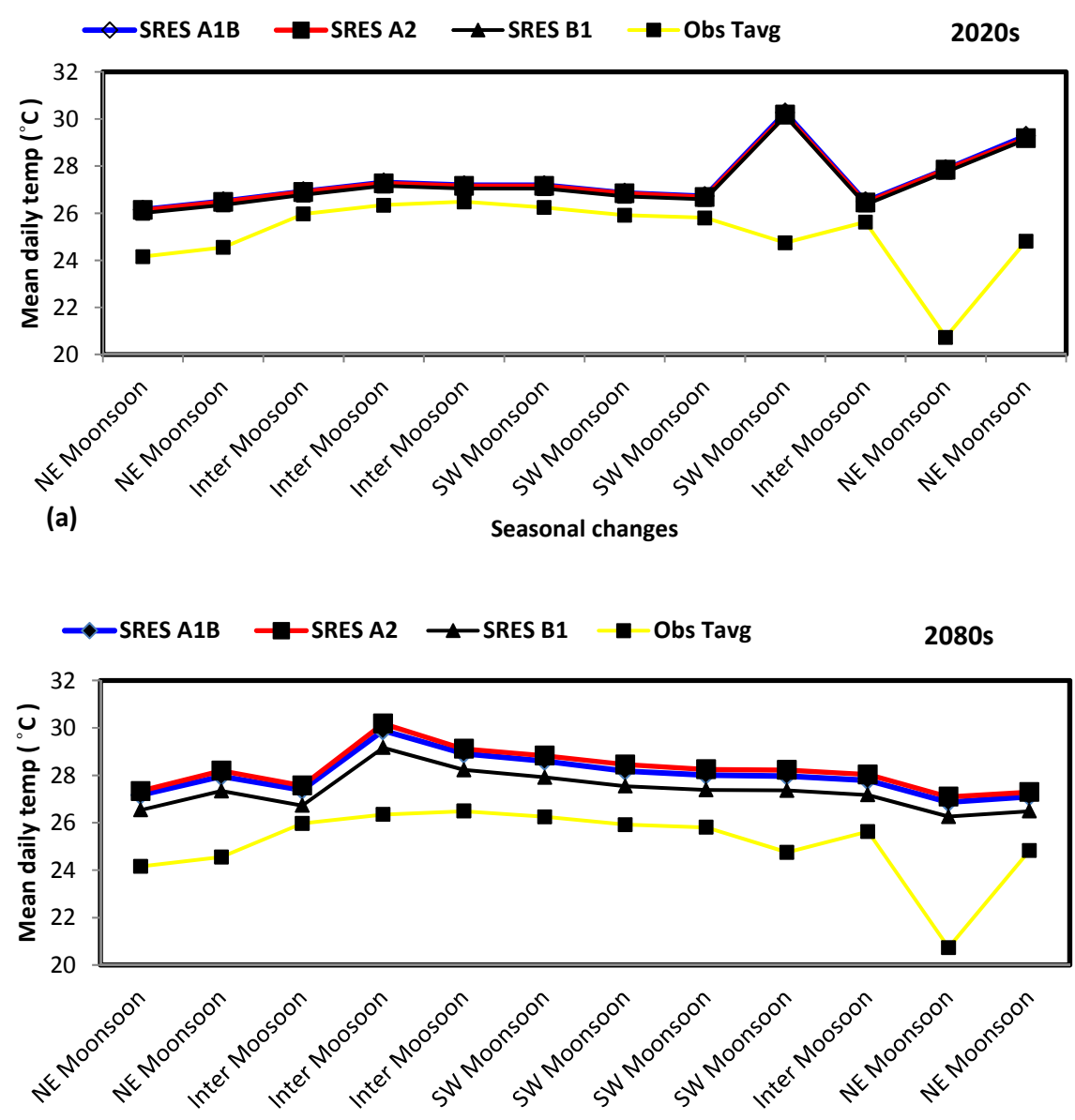

(b)

Seasonal changes

Figure 7. Plots for changes in seasonal and monthly precipitation under 45 scenarios for 2020s, 2080s and the observed trends

Table 5. Monthly changes in simulated climate variables compared to the observed period (1950-1999)

\begin{tabular}{ccccccc}
\hline $\begin{array}{c}\text { Observed Monthly } \\
\text { Average: }\end{array}$ & \multicolumn{2}{c}{ A1B Scenario: } & \multicolumn{2}{c}{ A2 Scenario: } & \multicolumn{2}{c}{ B1 Scenario: } \\
& $2000-2049$ & $2050-2099$ & $2000-2049$ & $2050-2099$ & $2000-2049$ & $2050-2099$ \\
$(1950-1999)$ & $(2020 \mathrm{~s})$ & $(2080 \mathrm{~s})$ & $(2020 \mathrm{~s})$ & $(2080 \mathrm{~s})$ & $(2020 \mathrm{~s})$ & $(2080 \mathrm{~s})$ \\
\hline Temp $=25.75$ & 1.65 & 2.24 & 1.6 & 2.46 & 1.51 & 1.59 \\
Prcp $=348 \mathrm{~mm}$ & 5 & 34 & -4 & 33 & 0 & 26 \\
\hline
\end{tabular}

\subsection{Precipitation and Recharge Estimate for the Study Area}

Climate change estimates were determined based on the precipitation change factors observed across the A2, $\mathrm{A} 1 \mathrm{~B}$ and B1 scenarios. The ensemble average of the precipitation change factors was computed for both 2020s and 2080s periods. The results of the recharge rate determined from the precipitation change factors and the computed ensemble average are presented in Figures 8a and 8b. Figure 8a, signature suggested a decrease in recharge rate between May and August and vice-versa between September and January in 2020s period. The signature in Figure 8b displayed recharge rate increase throughout the year except for the months of March and August where decrease rate is observed for the 2080s period. In comparison, the results shown in Figures 8a and $8 \mathrm{~b}$ correlated with precipitation change trend in Figures $4 \mathrm{a}$ and $4 \mathrm{~b}$. The trend analysis of the seasonal recharge rate variation across the predicted periods displayed varying magnitudes across the individual GCMs models 
(not shown) is similar to the trend shown in Figs $3 a$ and $3 b$. Relative to the ensemble projection trend, not more than four GCMs indicate a decrease in recharge rate during the southwest monsoon (June-September) and a rise in recharge rate is observed during northeast monsoon (October-November). The highest recharge rate is predicted to occur in November. For December, all the GCMs simulate a decrease in (2020s) and vice-versa in 2080s where the Miroc3 2 (medres) model displayed recharge rate increase as against other GCMSs showing decreasing magnitudes. Table 6 analysis gives the expected monthly percentage changes in recharge rate reference to the observed value (see Appendix B for recharge rate trend projection for A1B and B1 Scenarios).

\subsection{Temperature and Potential Evapotranspiration (PET) Estimates for the Study Area}

From analyzed results of the downscaled temperature change factor and its simulated ensemble average under the IPCC scenarios, the PET rate series were predicted for 2020s and 2080s periods in the area. Figures $9 \mathrm{a}$ and $9 \mathrm{~b}$ present PET rate trend projection across the individual GCMs models. Relatively, PET rate magnitudes are fairly uniform over the southwest monsoon (June-August) while an increase rate is observed between September and October in 2020s (Figure 9a). Also, in the 2080s projection (Figure 9b), the trend signature displayed over inter-monsoon season (April) shows a notable anomalously high PET rate whereas the southwest monsoon season is noted for a relatively fair uniform decreased rate. The lowest rate is observed within northeast monsoon seasons (November) across the study area. The result shown in Figure $8 \mathrm{~b}$ quite correlated with Figure $9 \mathrm{~b}$ trend projection particularly where the highest recharge rate recorded during the northeast season (November) (Figure 8b) suggested lowest PET rate observed in November (Figure 9b). The quantification of an expected monthly percentage change in PET rate reference to the observed value is presented in Table 6. In Table 6, the A2 scenario is of higher magnitude in terms of temperature increase compared to other scenarios. (See Appendix C for PET rate trend projection for A1B and B1 Scenarios).
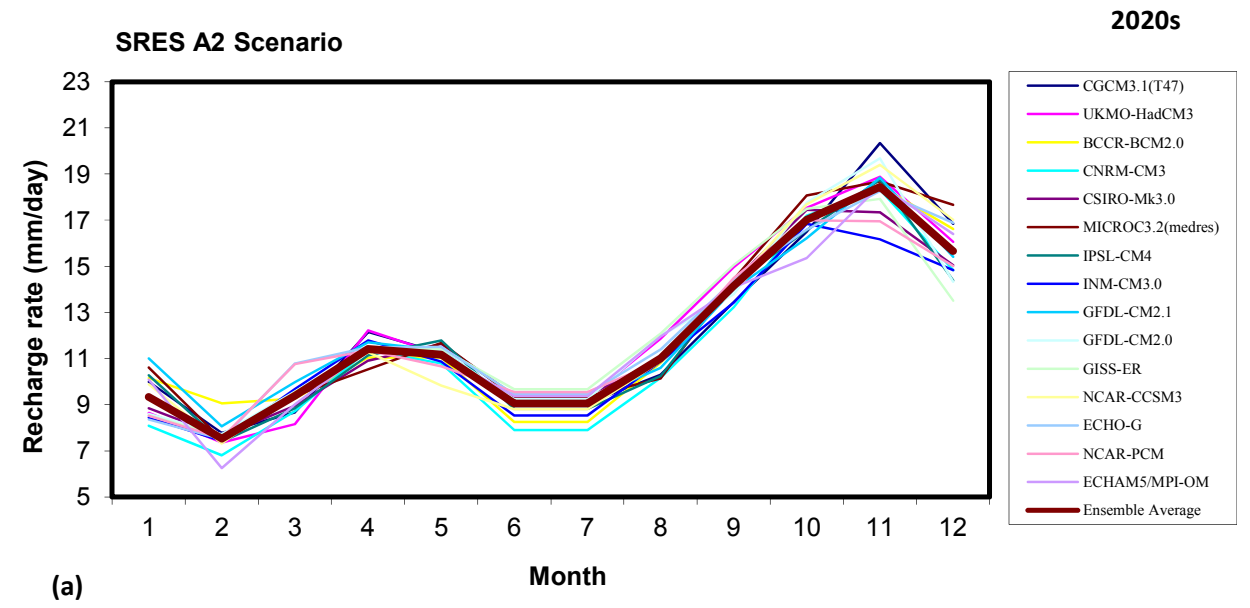

SRES A2 Scenario

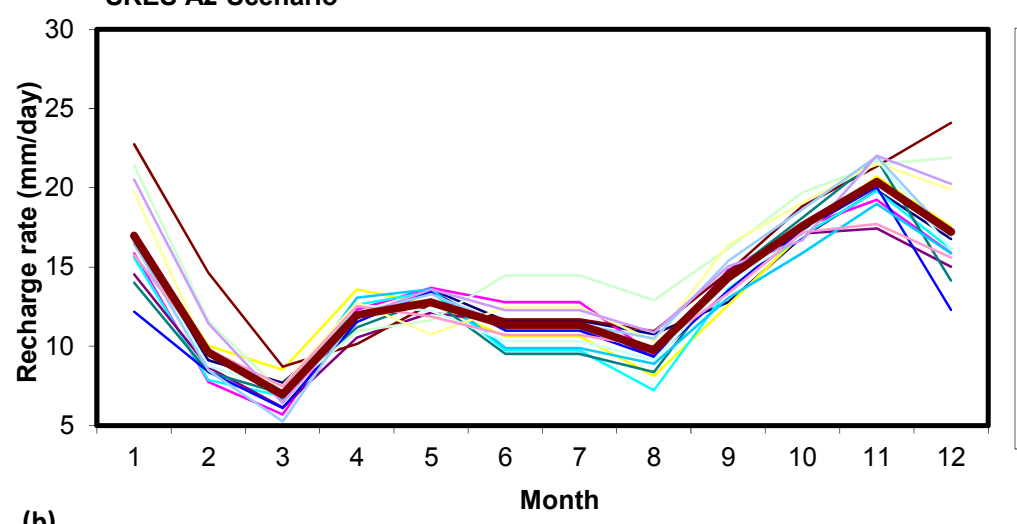

2080s

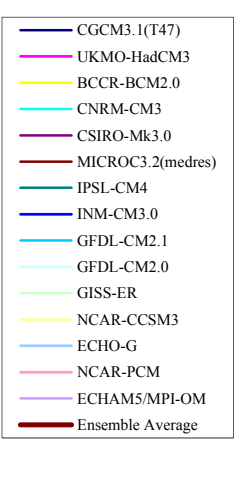

(b)

Figure 8. The projections of recharge rate estimates derived using Anderson et al. (1992) equation 

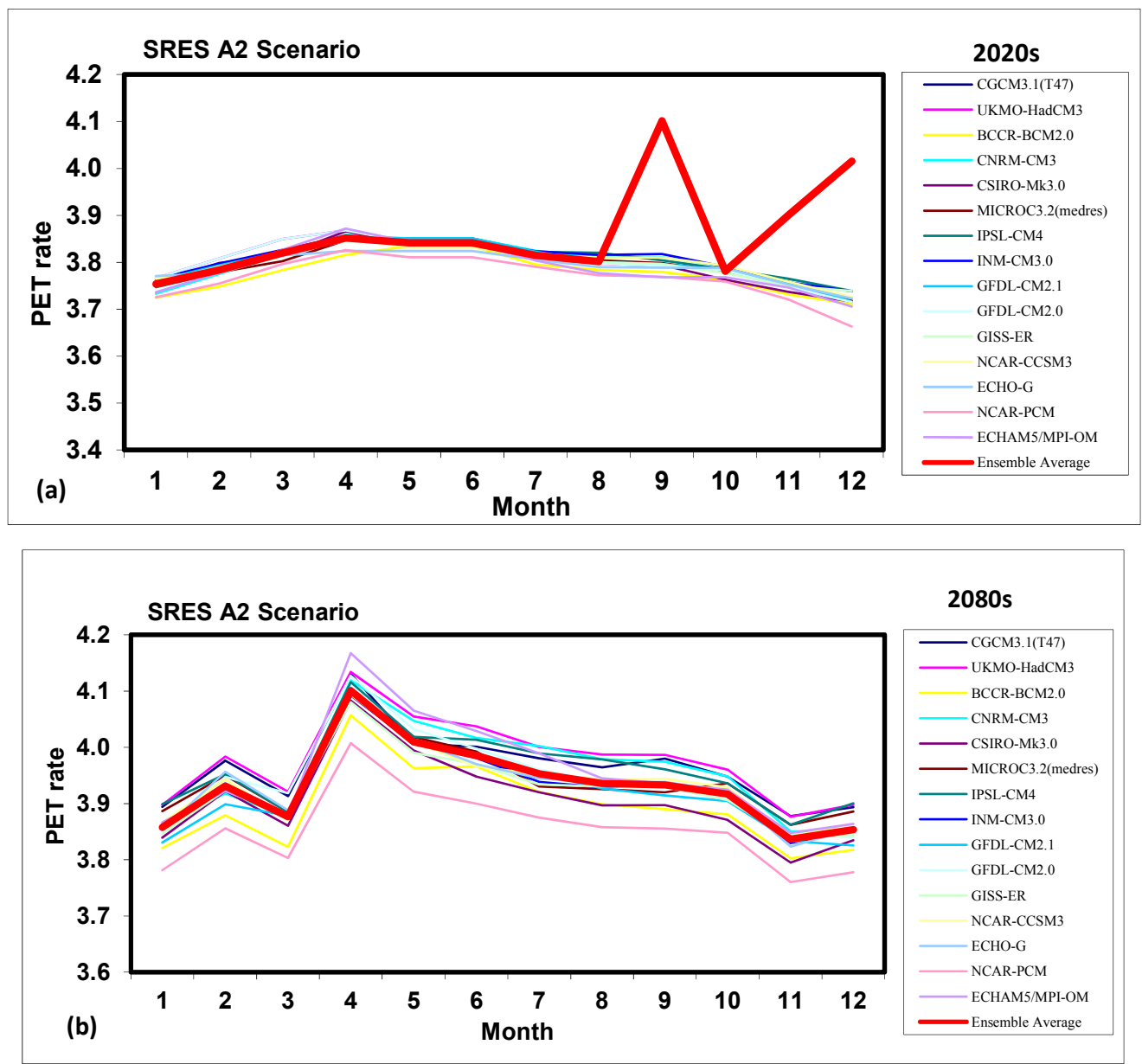

Figure 9. The projections of PET rate estimates derived using Blaney and Criddle, 1950 equation

Table 6. Monthly percentage changes in recharge rate reference to the observed value

\begin{tabular}{ccccccc}
\hline $\begin{array}{c}\text { Observed Monthly } \\
\text { Average: }\end{array}$ & \multicolumn{2}{c}{ A1B Scenario: } & \multicolumn{2}{c}{ A2 Scenario: } & \multicolumn{2}{c}{ B1 Scenario: } \\
$(1950-1999)$ & $2000-2049$ & $2050-2099$ & $2000-2049$ & $2050-2099$ & $2000-2049$ & $2050-2099$ \\
$(2020 \mathrm{~s})$ & $(2080 \mathrm{~s})$ & $(2020 \mathrm{~s})$ & $(2080 \mathrm{~s})$ & $(2020 \mathrm{~s})$ & $(2080 \mathrm{~s})$ \\
\hline $\mathrm{P}=348 \mathrm{~mm}$ & $1 \%$ & $10 \%$ & $-1 \%$ & $10 \%$ & $0 \%$ & $8 \%$ \\
PET $=3.72$ & $4 \%$ & $5 \%$ & $4 \%$ & $6 \%$ & $3 \%$ & $4 \%$ \\
Rech $=12.05$ & $1.30 \%$ & $10 \%$ & $-1.03 \%$ & $10 \%$ & $0.10 \%$ & $8 \%$
\end{tabular}

$\mathrm{P}=$ precipitation; PET: potential evapotranspiration; Rech: Recharge rate estimate.

\subsection{The Recharge and PET Rate Model Maps}

Figures 10 a, b, c and Figures 11 a, b, c show the spatial distribution of recharge and PET rate values obtained for the area. These results are presented to cover both the baseline period (1950-1999) and the future periods (2020s and 2080s) reflecting the regional climate change impact on the hydrological system of the area. According to the model maps the analyzed hydrological parameters (recharge and PET rate) values across the observed and the future periods vary between 12.05 to $17.83 \mathrm{~mm} /$ day and 3.72 to 4.05 , respectively (Figures 10 a, b, c and Figures $11 \mathrm{a}, \mathrm{b}, \mathrm{c})$. Figures 10b, 10c and Figures 11b, 11c were classified into different rating zones including Low (L), Medium (M) and High (H) recharge and PET rated zones using the determined observed rate values (12.05 and 3.72) as the bench mark. The quantitative results of the area coverage of the rated zones are presented in Tables 7 and 8. Based on Table 7 result, the spatial coverage of the recharge rate in the area is noted 
for a higher increase in 2080 s compare to 2020 s increment. Quantatively, more than $60 \%$ of the total area coverage is underlain by low recharge rating zone in 2020s. Considering the result presented in Table 5 , where the predicted precipitation in 2020s is very low, it was deduce that there is evidences of water crisis looming at this period. This result is in agreement with Azuhan Mohammad, 2012 investigation report, where he projected shortage of water supply up to year 2050 in Peninsular Malaysia. The spatially predicted PET rate for the future periods (Figures $11 \mathrm{~b}, \mathrm{c}$ ) shows the intense PET rate increase reference to the observed PET rating period in the area. The PET rate increases geometrically across the predicted periods 2020s and 2080s (Table 8). From the research findings according to Denmead and Shaw (1962), high PET rate does occur when soil moisture content is lowered as a result of inadequate recharge rate. As such, the area studied can be relatively zoned as an environment characterized with inadequate recharge rate. However, the high intensity of rainfall rate predicted for the 2080s (Table 5) is sufficient to augment the adverse impact of high PET rate on water supply in the study area. But for the low rainfall rate predicted for 2020s, the adverse impacts of high PET rate will severely affect water supply in the study area.

\subsection{Groundwater Status and Uncertainty Assessment}

The quantification of the effects of climate change on potential recharge and PET rates across the predicted time horizons (2020s and 2080s) in comparison with the baseline period data has established the evidences of future impact of climate change in the study area transboundary system. The results of the ensemble average suggest $1 \%$ reduction in potential recharge rate in 2020s period. In 2080s, the potential recharge increment varies between $7 \%$ and $10 \%$. The reduction and recharge increment in $2020 \mathrm{~s}$ and $2080 \mathrm{~s}$, respectively quite compliment the recharge rate prediction remark across the considered IPCC scenarios (Tables 9 and 10). The A2 scenario is noted for higher vote under decrease remark compare to other scenarios in 2020. Furthermore, the general assessment of the multiple GCMs models ensemble average output across the A1B, B1 and A2 scenarios predicted a 90\% increase in potential recharge in the area with an exceptional decreased prediction in A2 scenario particularly in the 2020s. This is extraordinary attributes of A2 scenario could be because it has higher rate of GHG emission under its IPCC scenario category. As such, A2 scenario's adverse impact on the environment is more severe compare to other scenarios. In this study, the prediction output of the individual GCMs model differs significantly from each other with their spread over a wide prediction range, covering both increases and decreases in recharge trend of the area. The wide prediction range variation in the individual GCMs model doesn't provide probable outcomes unlike the ensemble average prediction (see Appendix D). This implies that individual GCMs models predictions are associated with existence of uncertainties in assessment of climate change impact on water resources (New et al., 2007). The 90\% recharge increase predicted based on the ensemble average estimates across all the emission scenarios has provided the highest likelihood mean estimate as well as a measure of its uncertainty and less probable outcomes. This result is in agreement with the approach of Weigel et al. (2008) who combines multiple models that typically result in error cancellation in climate forecasts. Therefore, the above analysis confirmed the prediction accuracy of ensemble average better than single model output.

The predicted reduction in recharge rate due to decrease in precipitation and increase in evapotranspiration of the area is liable to cause lowering of groundwater level, reduction in groundwater volume/quantity etc. The hydrological implication of these defects will severely affect the groundwater status in the study area particularly in 2020s. It is therefore recommended that the water resource manager should put up a remediation measures to guide the groundwater resources sustainability under future climate change scenario such as reduction in net aquifer extractions through controlling pumping rate for onward conservation and greater efficiency of the water resource management in the study area. 

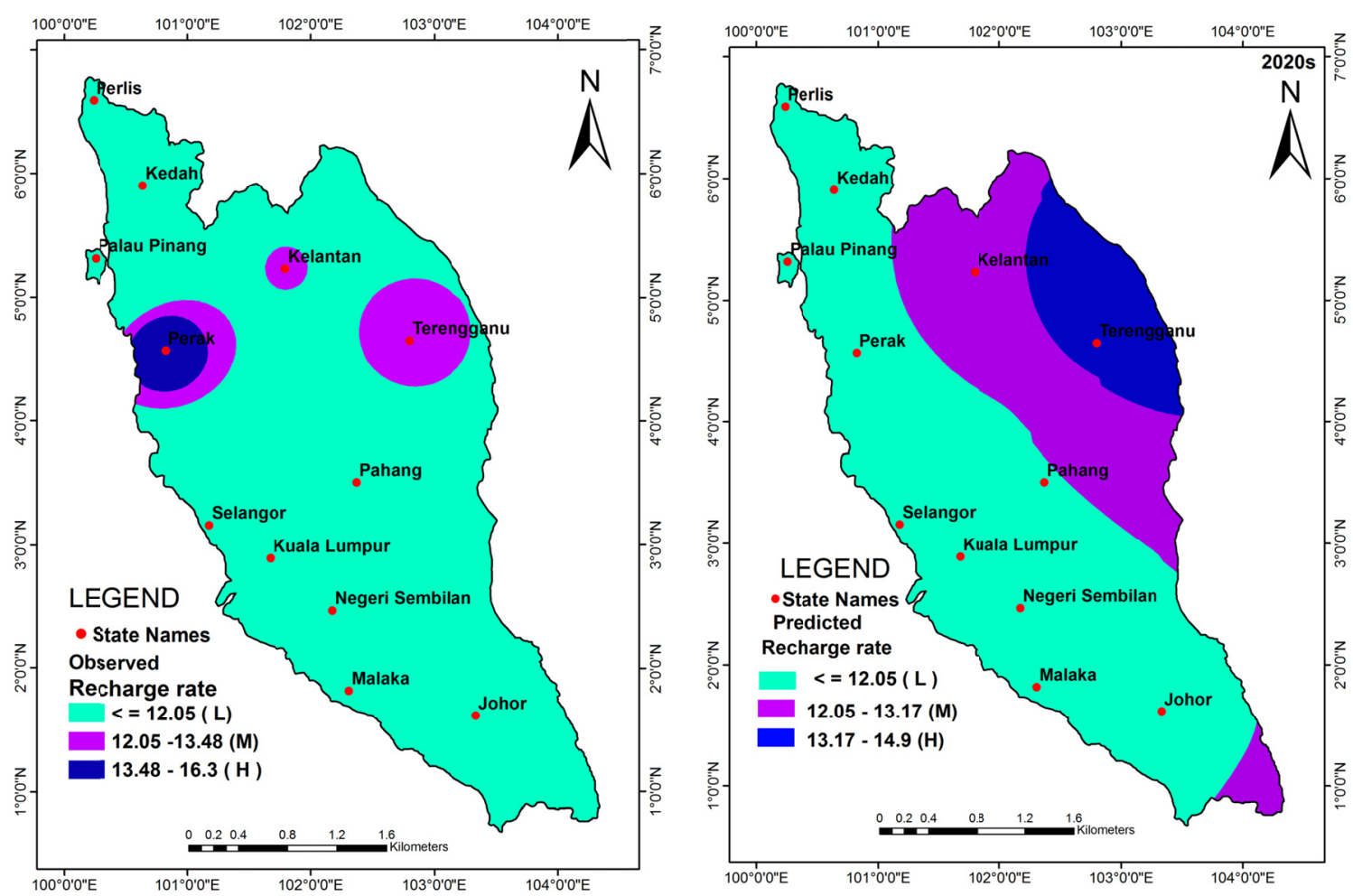

(a)

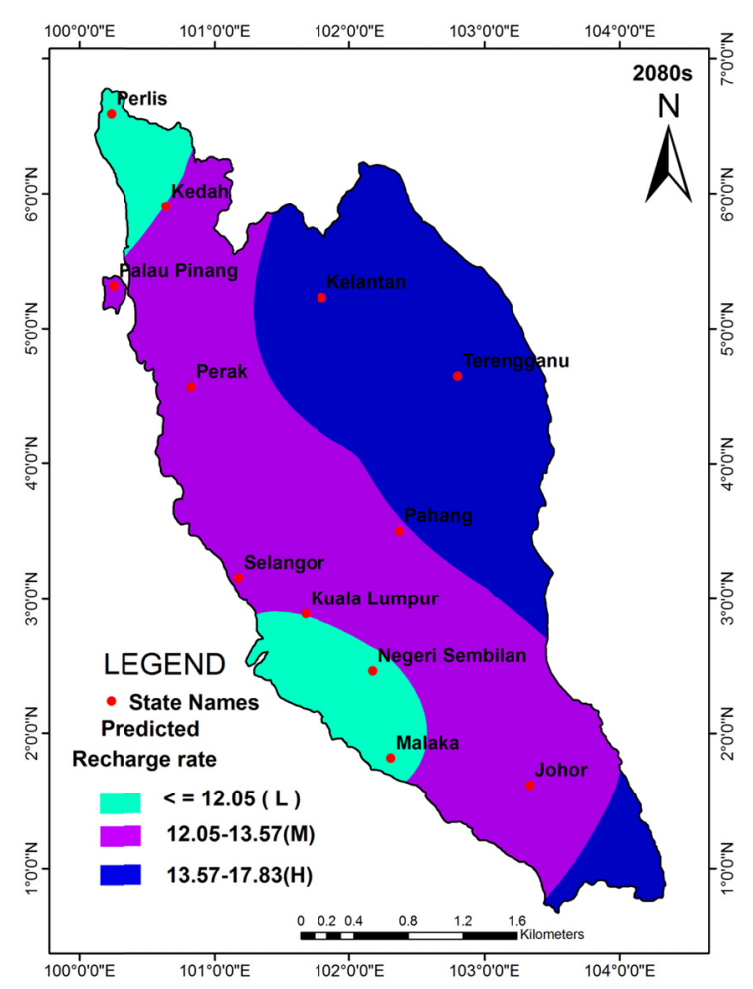

(c)

Figure 10. Recharge rate

(a) observed map of the area; (b) prediction map of the area; (c) prediction map of the area 

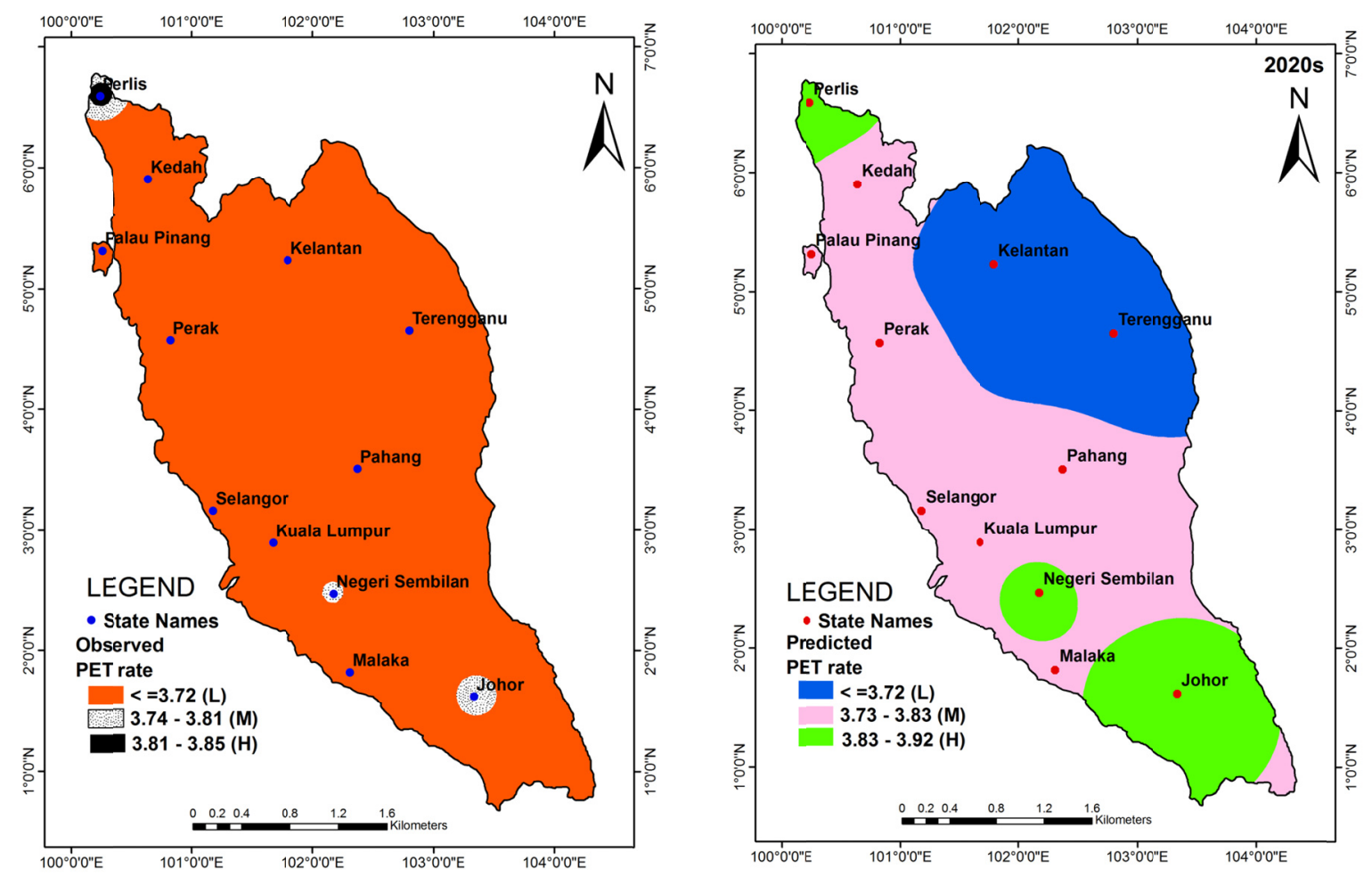

(a)

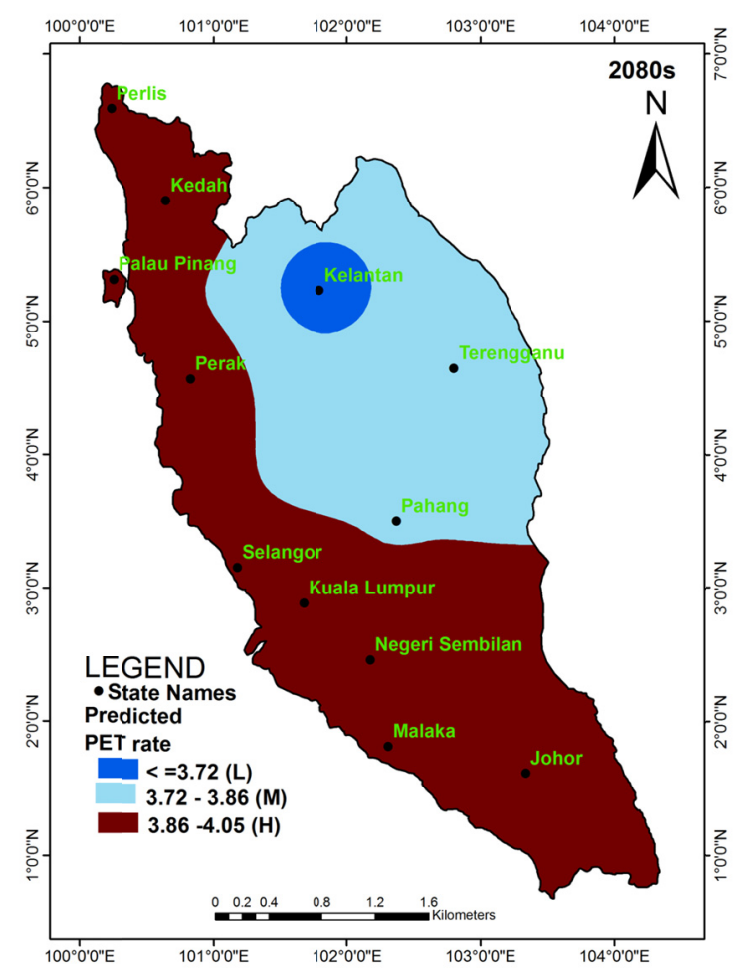

(c)

Figure 11. PET rate

(a) observed map of the area; (b) prediction map of the area; (c) prediction map of the area 
Table 7. Percentage recharge rate spatial coverage

\begin{tabular}{cccc}
\hline Zones & Observed & $2020 \mathrm{~s}$ & $2080 \mathrm{~s}$ \\
\hline Low $(\mathrm{L})$ & $63 \%$ & $63 \%$ & $16 \%$ \\
Medium $(\mathrm{M})$ & $23 \%$ & $26 \%$ & $38 \%$ \\
$\operatorname{High}(\mathrm{H})$ & $14 \%$ & $11 \%$ & $46 \%$ \\
\hline
\end{tabular}

Table 8. Percentage PET rate spatial coverage

\begin{tabular}{cccc}
\hline Zones & Observed & $2020 \mathrm{~s}$ & $2080 \mathrm{~s}$ \\
\hline Low $(\mathrm{L})$ & $67 \%$ & $29 \%$ & $10 \%$ \\
Medium(M) & $22 \%$ & $50 \%$ & $29 \%$ \\
High(H) & $11 \%$ & $21 \%$ & $61 \%$ \\
\hline
\end{tabular}

Table 9. Model prediction analysis for 2020 s

\begin{tabular}{cccc}
\hline \multicolumn{4}{c}{ Prediction remark } \\
\hline No of GCM use & Scenarios & Increase & Decrease \\
\hline 15 & A1B & 12 & 3 \\
15 & A2 & 3 & 9 \\
15 & B1 & 8 & 7 \\
\hline
\end{tabular}

Table 10. Model prediction analysis for 2080s

\begin{tabular}{cccc}
\hline \multicolumn{4}{c}{ Prediction remark } \\
\hline No of GCM use & Scenarios & Increase & Decrease \\
\hline 15 & A1B & 15 & - \\
15 & A2 & 15 & - \\
15 & B1 & 15 & - \\
\hline
\end{tabular}

\section{Conclusion and Recommendation}

Groundwater resource is an invaluable natural resource that had contributed immensely to the water resource forces of the world. It is necessary to assess the possible effects of climate change on this invaluable resource so that timely adaptation strategies can be formulated for onward sustainability of the resources. This study presents a methodology to predict a regional potential climate change impacts on the groundwater resource in temperate region which applied to Peninsular Malaysia. An empirical modeling equation, GIS-based geostatistical technique and optimization model forecasting accuracy approaches were adopted in this study.

The study incorporates climate projections from a group of 15 GCMs models run under 3 different global climate IPCC scenarios to provide an assessment of potential climate change impact on regional groundwater resources in the area. A range of predictions is obtained by modeling the precipitation and temperature change factors derived from the multiple GCMs models run under three (3) future emission scenarios, A1B, A2 and B1 for 50 years periods from 2000 to 2049 (2020s) and 2050 to 2099 (2080s) reference to the baseline period (1950 to 1999) using recharge and PET modeling equations. The following facts were established in this study:

-Average temperature changes will rise from $1.51-2.46{ }^{\circ} \mathrm{C}$, with the greatest increase in September $(2020 \mathrm{~s})$ and April (2080s) corresponding to the inter monsoon seasons of the study area.

-The range of precipitation changes within each month for 2080s are much higher than those for 2020s due to northeast monsoon increase precipitation.

-The lowest precipitation occurs during southwest monsoon season in the study area.

-The predicted estimated recharge rate for the study area varies between 12.05 and $17.83 \mathrm{~mm} /$ day. 
-The ensemble average prediction suggests there will be a $1 \%$ reduction in monthly recharge rate in 2020 s and $7-10 \%$ recharge increment in $2080 \mathrm{~s}$.

-More than $60 \%$ of the spatial coverage of the study area are underlain by low rated recharge zones.

-The efficacy of ensemble average forecasting accuracy is compared with individual GCMs prediction.

Based on the above findings, evidences are shown to establish the future potential impact of climate change on water recourses in the study area particularly in 2020s (2000-2050).

Assessing the potential climate change impacts on the water resources of the Peninsular Malaysia transboundary system provides a powerful insight on the degree of vulnerability of groundwater resources to such changes. The inclusion of these potential impacts on the groundwater hydrology in the study area's decision support system (DSS) model will support water managers in evaluating conservation strategies and provide a prompt remediation measures to safeguard the groundwater resources sustainability under future scenarios.

\section{Acknowledgments}

This project was carried out using the financial support from COMSTECH-TWAS: Development of A New Algorithm for Land Use and Greenhouse Gases Concentration in Peninsular Malaysia and the Development of an Algorithm and a Model Through Image Processing. The provider of the globally downscaled climate data obtained from www.engr.scu.edu/ emaurer/global_data is highly acknowledged. Thanks are also extended to USM for support and encouragement.

\section{References}

Adam, J. C., \& Lettenmaier, D. P. (2003). Adjustment of global gridded precipitation for systematic bias. $J$. Geophys. Res., 108, 1-14. http://dx.doi.org/10.1029/2002JD002499

Akhtar, M., Ahmad, N., \& Booij, M. J. (2008). The impact of climate change on the water resources of Hindukush-Karakorum-Himalaya region under different glacier coverage scenarios. Journal of Hydrology, 355(1), 148-163. http://dx.doi.org/10.1016/j.jhydrol.2008.03.015

Anderson, M. P., \& Woessner, W. W. (1992). Applied groundwater modeling. San Diego, CA: Academic Press. http://dx.doi.org/10.1111/j.1745-6584.1998.tb02108.x

Anderson, T. W., Freethey, G. W., \& Patrick, T. (1992). Geohydrology and Water Resources of Alluvial Basins in South central Arizona and Parts of Adjacent States, U.S. Geological Survey Professional Paper 1406-B, United States Government Printing Office, Washington.

Azuhan, M. (2012). Reports article on utilization of groundwater resources in Peninsular Malaysia.

Bates, B. C., Kundzewicz, Z. W., Wu, S., \& Palutikof, J. (2008). Climate change and water. Technical paper of the Intergovernmental Panel on Climate Change, IPCC Secretariat, Geneva.

Blaney, H. F., \& Criddle, W. D. (1950). Determining water requirements in irrigated area from climatological irrigation data. US Dept Agric., Soil Conservation Service, Tech. Paper no. 96.

Bloomfield, J. P., Williams, R. J., Gooddy, D. C, Cape, J. N., \& Guha, P. (2006). Impacts of climate change on the fate and behaviour of pesticides in surface and groundwater-a UK perspective. Science of The Total Environment, 369(1), 163-177. http://dx.doi.org/10.1016/j.scitotenv.2006.05.019

Brouyère, S., Carabin, G., \& Dassargues, A. (2004). Climate change impacts on groundwater resources: modelled deficits in a chalky aquifer, Geer basin, Belgium. Hydrogeology Journal, 12(2), 123-134. http://dx.doi.org/10.1007/s10040-003-0293-1

Chen, J. S., Li, L., Wang, J. Y., Barry, D. A., Sheng, X. F., Gu, W. Z., \& Chen, L. (2004). Water resources: groundwater maintains dune landscape. Nature, 432(7016), 459-460. http://dx.doi.org/10.1038/432459a

Chen, Y., Takeuchi, K., Xu, C., \& Xu, Z. (2006). Regional climate change and its effects on river runoff in the Tarim Basin, China. Hydrological Processes, 20(10), 2207-2216. http://dx.doi.org/10.1002/hyp.6200

Chiew, F. H. S. (2006). Estimation of rainfall elasticity of streamflow in Australia. Hydrological Sciences Journal, 51(4), 613-625. http://dx.doi.org/10.1623/hysj.51.4.613

Christensen, N. S., Wood, A. W., Voisin, N., Lettenmaier, D. P., \& Palmer, R. N. (2004). The effects of climate change on the hydrology and water resources of the Colorado River basin. Climatic Change, 62(1), 337-363. http://dx.doi.org/10.1023/B:CLIM.0000013684.13621.1f 
Collison, A., Wade, S., Griffiths, J., \& Dehn, M. (2000). Modelling the impact of predicted climate change on landslide frequency and magnitude in SE England. Engineering Geology, 55(3), 205-218. http://dx.doi.org/10.1016/S0013-7952(99)00121-0

Denmead, O. T., \& Shaw, R. H. (1962). Availability of soil water to plants as affected by soil moisture content $\begin{array}{llll}\text { and meteorological } & \text { conditions. } & \text { 3gronomy }\end{array}$ http://dx.doi.org/10.2134/agronj1962.00021962005400050005x

Devineni, N., \& Sankarasubramanian, A. (2010). Improved categorical winter precipitation forecasts through multimodel combinations of coupled GCMs. Geophysical Research Letters, 37(24), L24704. http://dx.doi.org/10.1029/2010GL044989

Eckhardt, K., \& Ulbrich, U. (2003). Potential impacts of climate change on groundwater recharge and streamflow in a central European low mountain range. Journal of Hydrology, 284(1-4), 244-252. http://dx.doi.org/10.1016/j.jhydrol.2003.08.005

Fowler, H. J., Kilsby, C. G., \& O'Connell, P. E. (2003). Modeling the impacts of climatic change and variability on the reliability, resilience, and vulnerability of a water resource system. Water Resources Research, 39(8), 1222. http://dx.doi.org/10.1029/2002WR001778

Fowler, H. J., Kilsby, C. G., \& Stunell, J. (2007). Modelling the impacts of projected future climate change on water resources in north-west England. Hydrology and Earth System Sciences, 11(3), 1115-1126. http://dx.doi.org/10.5194/hess-11-1115-2007

Gao, X., Shi, Y., Song, R., Giorgi, F., Wang, Y., \& Zhang, D. (2008). Reduction of future monsoon precipitation over China: Comparison between a high resolution RCM simulation and the driving GCM. Meteorology and Atmospheric Physics, 100(1), 73-86. http://dx.doi.org/10.1007/s00703-008-0296-5

Goderniaux, P., Brouyère, S., Fowler, H. J., Blenkinsop, S., Therrien, R., Orban, P., \& Dassargues, A. (2009). Large scale surface-subsurface hydrological model to assess climate change impacts on groundwater reserves. Journal of Hydrology, 373(1-2), 122-138. http://dx.doi.org/10.1016/j.jhydrol.2009.04.017

IPCC. (2007). The Physical Science Basis. Contribution of Working Group I to the Fourth Assessment Report of the Intergovernmental Panel on Climate Change. Cambridge University Press, Cambridge, United Kingdom and New York, NY, USA, 996, 2007.

IPCC. (2008). Technical paper on climate change and water. IPCC-XXVIII/ Doc.13 (8.IV.2008). IPCC Secretarial Geneva. Retrieved on 15 May 2008 from http://www.ipcc.ch/meetings/session28/doc13.pdf

Jiang, T., Chen, Y. D., Xu, C., Chen, X., \& Singh, V. P. (2007). Comparison of hydrological impacts of climate change simulated by six hydrological models in the Dongjiang Basin, South China. Journal of Hydrology, 336(3), 316-333. http://dx.doi.org/10.1016/j.jhydrol.2007.01.010

Johnston, K., Hoef, J. M. V., Krivoruchko, K., \& Lucas, N. (2003). Using ArcGIS Geostatistical Analyst. Printed in the United States of America.

Kay, A. L., Jones, R. G., \& Reynard, N. S. (2006). RCM rainfall for UK flood frequency estimation. II. Climate change results. Journal of Hydrology, 318(1), 163-172. http://d.doi.org/10.1016/j.jhydrolol.2005.06.013

Labat, D., Goddéris, Y., Probst, J. L., \& Guyot, J. L. (2004). Evidence for global runoff increase related to climate warming. Advances in Water Resources, 27(6), 631-642. http://dx.doi.org/10.1016/j.advwatres.2004.02.020

Maurer, E. P., Adam, J. C., \& Wood, A. W. (2009). Climate model based consensus on the hydrologic impacts of climate change to the Rio Lempa basin of Central America. Hydrology and Earth System Sciences, 13(2), 183. http://dx.doi.org/10.5194/hess-13-183-2009

Mc Carthy, J. J., Canziani, O. F, Leary, N. A., Dokken, D. J., \& White, K. S. (2001). Climate change-impacts, adaptation and vulnerability. Contribution of working group II to the third assessment report of the intergovernmental panel on climate change. Cambridge, United Kingdom and New York, NY, USA: Cambridge University Press. p. 1032.

Mimikou, M. A., Baltas, E., Varanou, E., \& Pantazis, K. (2000). Regional impacts of climate change on water resources quantity and quality indicators. Journal of Hydrology, 234(1), 95-109. http://dx.doi.org/10.1016/S0022-1694(00)00244-4 
New, M., Lopesz, A., Dessai, S., \& Wilby, R. (2007). Challenges in using probabilistic climate change information for impact assessments: an example from water. Philosophical Transaction of the royal society a-Mathematical Physical and Engineering Sciences, 365(1857), 2117-2131.

Perry, H., \& Landsberg, H. H. (1977). Projected world energy consumption. Energy and climate: Studies in geophysics, National Academy of Sciences, Washington, DC.

Philip, M. N., \& Batelaan, O. (2009). Estimating the effects of climate change on groundwater recharge and baseflow in the upper Ssezibwa catchment, Uganda. Hydrological sciences journal, 54(4), 713-726. http://dx.doi.org/10.1623/hysj.54.4.713

Piao, S., Ciais, P., Huang, Y., Shen, Z., Peng, S., Li, J., \& Ding, Y. (2010). The impacts of climate change on water resources and agriculture in China. Nature, 467(7311), 43-51. http://dx.doi.org/10.1038/nature09364

Ranjan, P., Kazama, S., \& Sawamoto, M. (2006). Effects of climate change on coastal fresh groundwater $\begin{array}{lllll}\text { resources. } & \text { Global } & \text { Environmental } & \text { Change, } & \text { 16(4), }\end{array}$ http://dx.doi.org/10.1016/j.gloenvcha.2006.03.006

Scibek, J., \& Allen, D. M. (2006). Comparing modelled responses of two high-permeability, unconfined aquifers to predicted climate change. Global and Planetary Change, 50(1-2), 50-62. http://dx.doi.org/10.1016/j.gloplacha.2005.10.002

Scibek, J., Allen, D. M., Cannon, A. J., \& Whitfield, P. H. (2007). Groundwater-surface water interaction under scenarios of climate change using a high-resolution transient groundwater model. Journal of Hydrology, 333(2-4), 165-181. http://dx.doi.org/10.1016/j.jhydrol.2006.08.005

Serrat-Capdevila, A., Valdés, J. B., Pérez, J. G., Baird, K., Mata, L. J., \& Maddock III, T. (2007). Modeling climate change impacts-and uncertainty-on the hydrology of a riparian system: The San Pedro Basin (Arizona/Sonora). Journal of Hydrology, 347(1-2), 48-66. http://dx.doi.org/10.1016/j.jhydrol.2007.08.028

Shaaban, A. J., Amin, M. Z. M., Chen, Z. Q., \& Ohara, N. (2011). Regional Modeling of Climate Change Impact on Peninsular Malaysia Water Resources. Journal of Hydrologic Engineering, 16, 1040. http://dx.doi.org/10.1061/(ASCE)HE.1943-5584.0000305

Todd, D. K., \& Mays, L. W. (2005). Groundwater Hydrology. Hoboken: Wiley.

Van Rheenen, N. T., Wood, A. W., Palmer, R. N., \& Lettenmaier, D. P. (2004). Potential implications of PCM climate change scenarios for Sacramento-San Joaquin River basin hydrology and water resources. Climatic Change, 62(1), 257-281. http://dx.doi.org/10.1023/B:CLIM.0000013686.97342.55

Van Roosmalen, L., Christensen, B. S. B., \& Sonnenborg, T. O. (2007). Regional differences in climate change impacts on groundwater and stream discharge in Denmark. Vadose Zone Journal, 6(3), 554-571. http://dx.doi.org/10.2136/vzj2006.0093

Weigel, A. P., Liniger, M. A., \& Appenzeller, C. (2008). Can multi-model combination really enhance the prediction skill of probabilistic ensemble forecasts? Quarterly Journal of the Royal Meteorological Society, 134(630), 241-260. http://dx.doi.org/10.1002/qj.210

Weisheimer, A., Doblas-Reyes, F. J., Palmer, T. N., Alessandri, A., Arribas, A., Déqué, M., \& Rogel, P. (2009). ENSEMBLES: A new multi-model ensemble for seasonal-to-annual predictions-Skill and progress beyond DEMETER in forecasting tropical Pacific SSTs. Geophysical research letters, 36(21), L21711. http://dx.doi.org/10.1029/2009GL040896

Wood, A. W., Leung, L. R., Sridhar, V., \& Lettenmaier, D. P. (2004). Hydrologic implications of dynamical and statistical approaches to downscaling climate model outputs. Climatic Change, 62(1), 189-216. http://dx.doi.org/10.1023/B:CLIM.0000013685.99609.9e

Xu, M., Chang, C. P., Fu, C., Qi, Y., Robock, A., Robinson, D., \& Zhang, H. (2006). Steady decline of east Asian monsoon winds, 1969-2000: Evidence from direct ground measurements of wind speed. J. Geophys. Res, 111, D24111. http://dx.doi.org/10.1029/2006JD007337

Zhang, Q., Xu, C. Y., Zhang, Z., Chen, Y. D., \& Liu, C. L. (2008a). Spatial and temporal variability of precipitation maxima during 1960-2005in the Yangtze River basin and possible association with largescale circulation. J. Hydrol, 353, 215-227. http://dx.doi.org/10.1016/j.jhydrol.2007.11.023

Zhang, Q., Xu, C. Y., Gemmer, M., Chen, Y. D., \& Liu, C. L. (2008b). Changing properties of precipitation concentration in the Pearl River basin, China. Stoch Env Res Risk A, 23(3), 377-385. http://dx.doi.org/10.1007/s00477-008-0225-7 
Appendix A. Regional precipitation projection of the 15 GCMs. The four best performing models were highlighted (Echam5-MPI-OM, Miroc3_2(medres), UKMO-HadCM3, GISS-ER: Trends for scenario A1B \& B1.
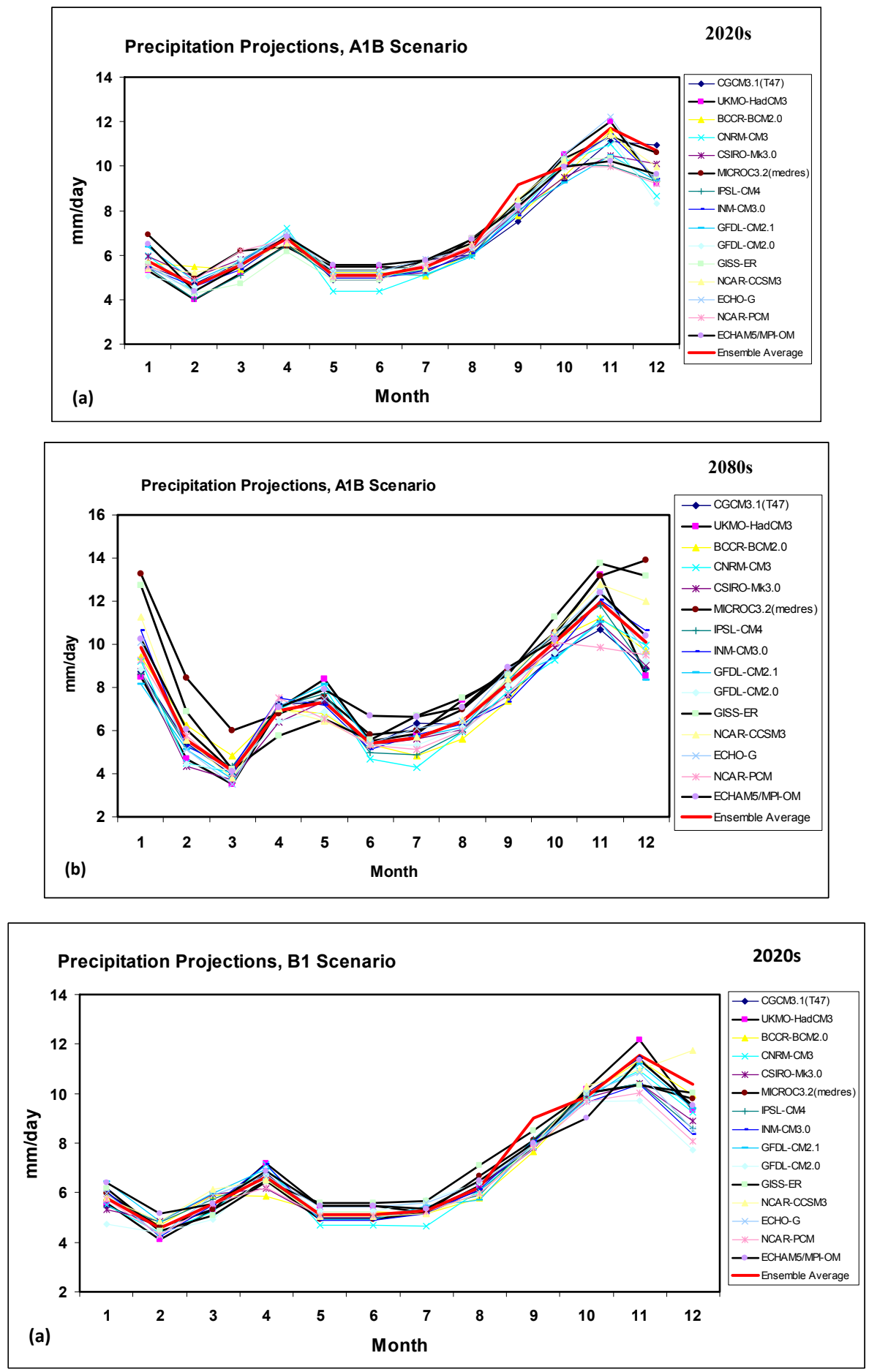


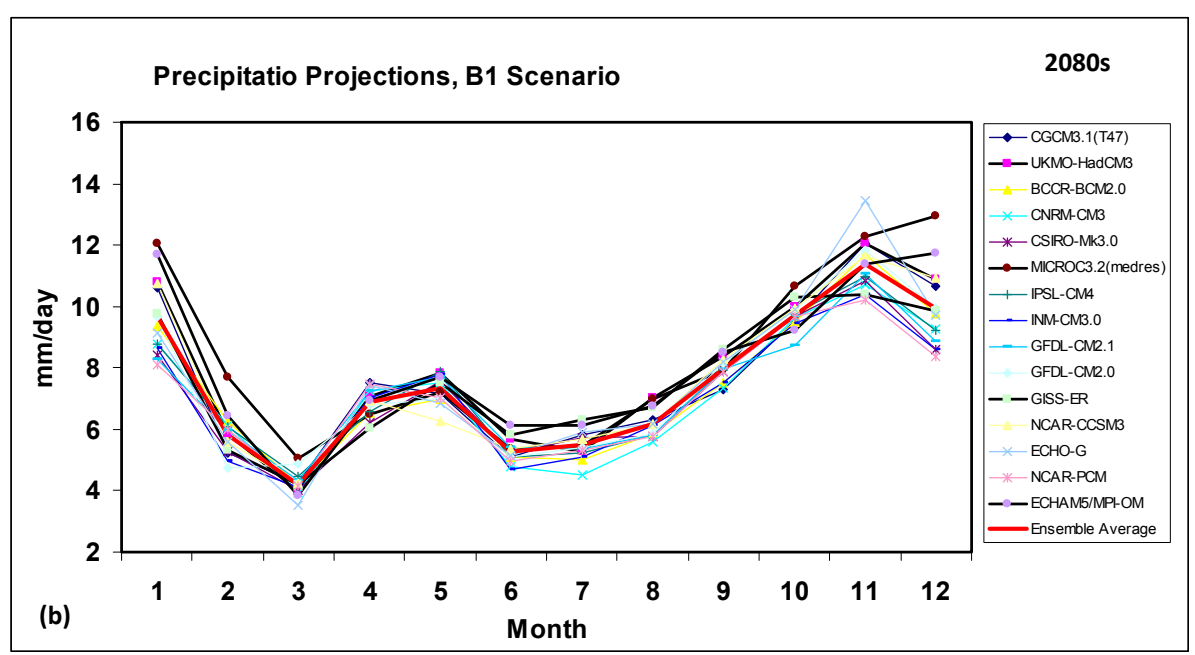

Appendix B. The projections of Recharge rate estimates derived using Anderson et al. (1992) equation for Scenario A1B and B1.
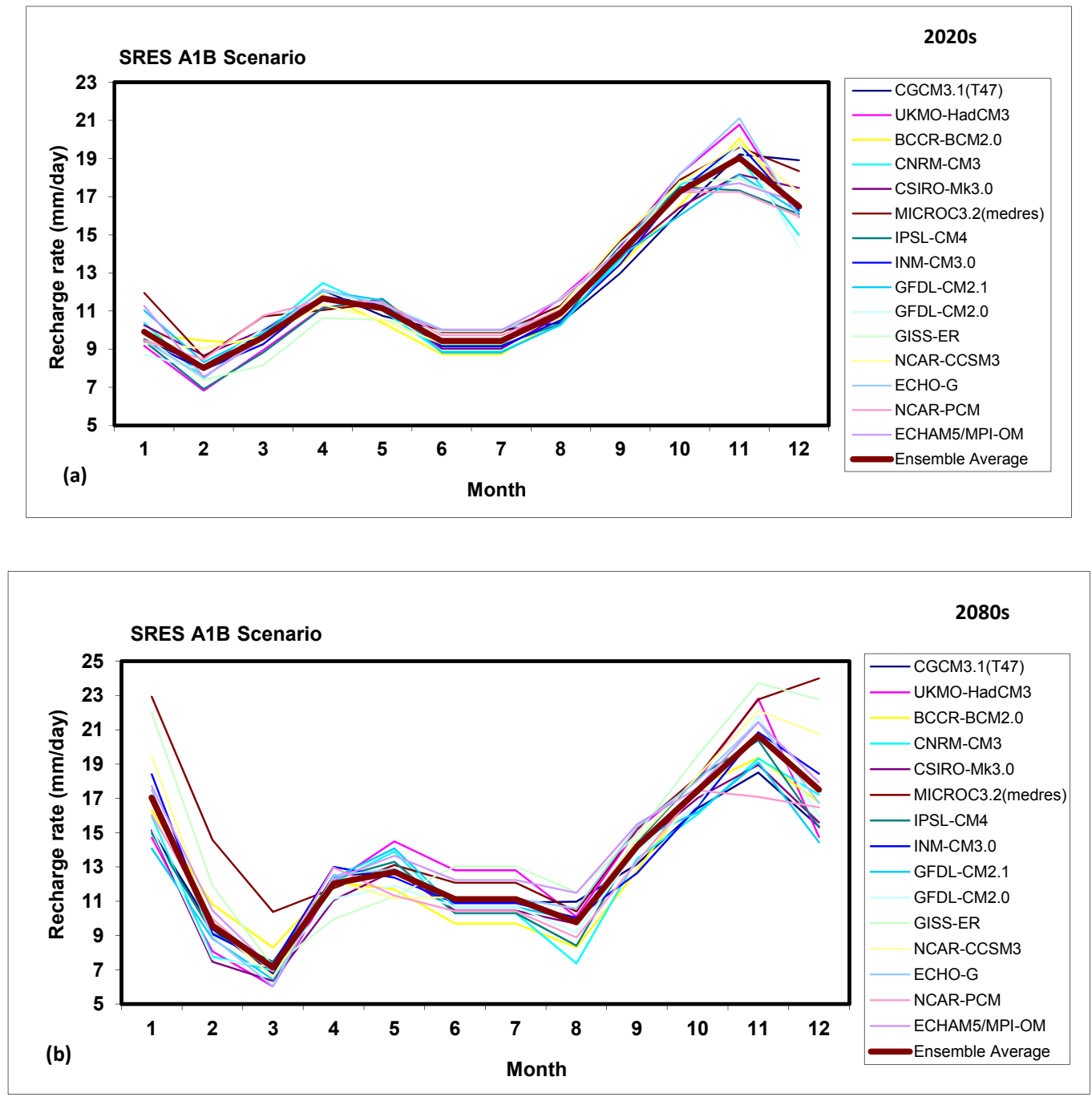

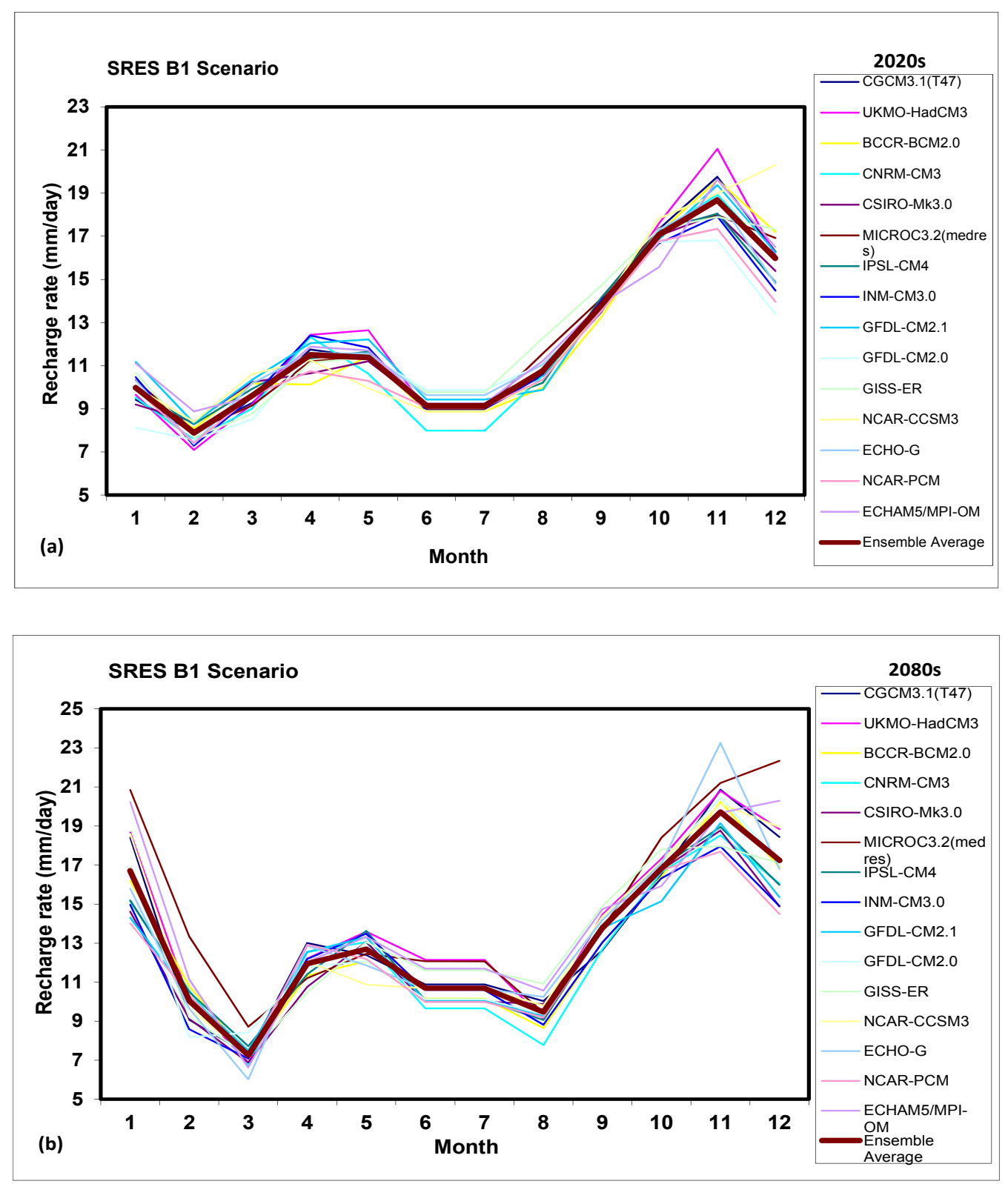
Appendix C. The projections of PET rate estimates derived using Blaney and Criddle, 1950 equation.
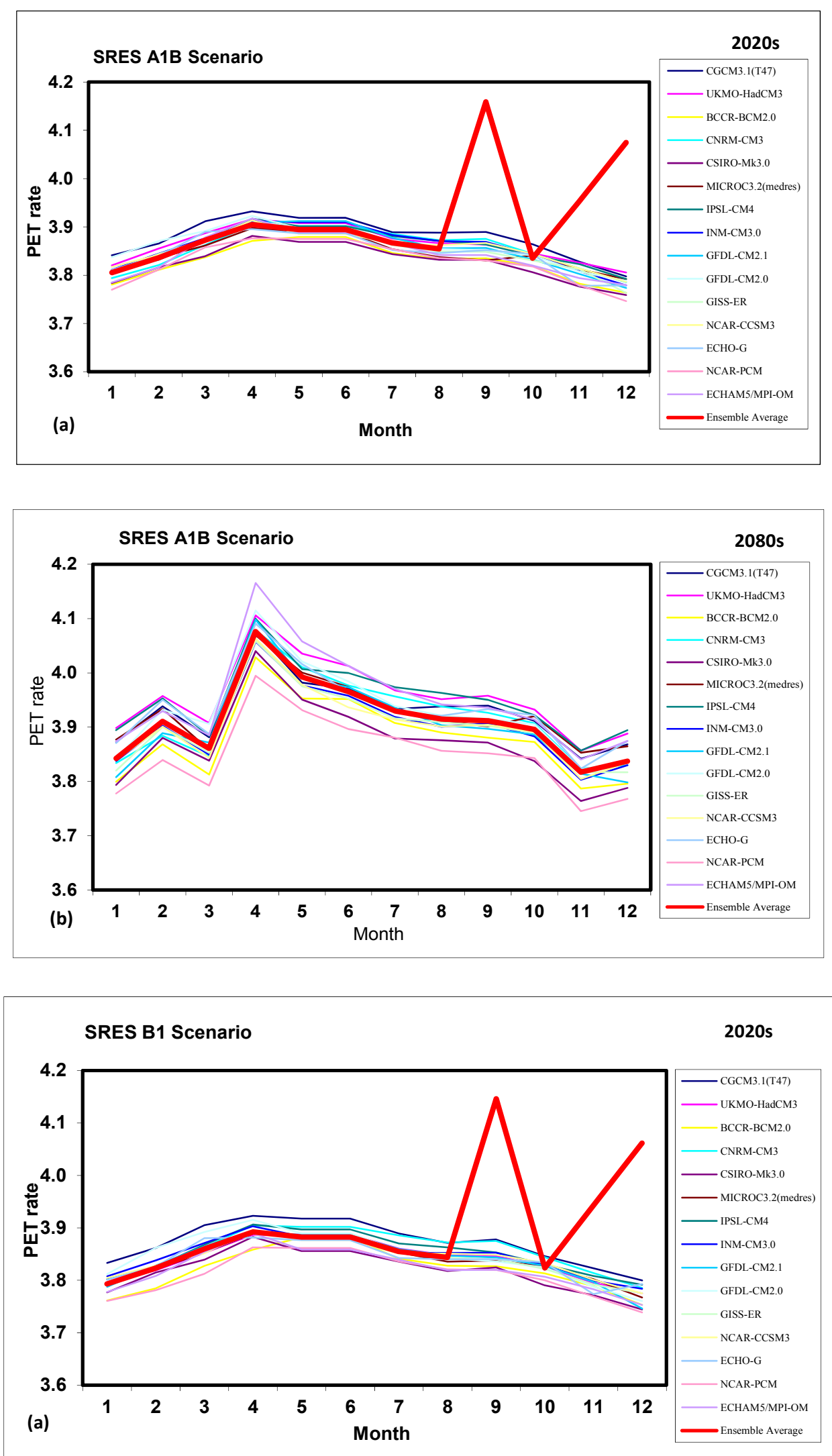


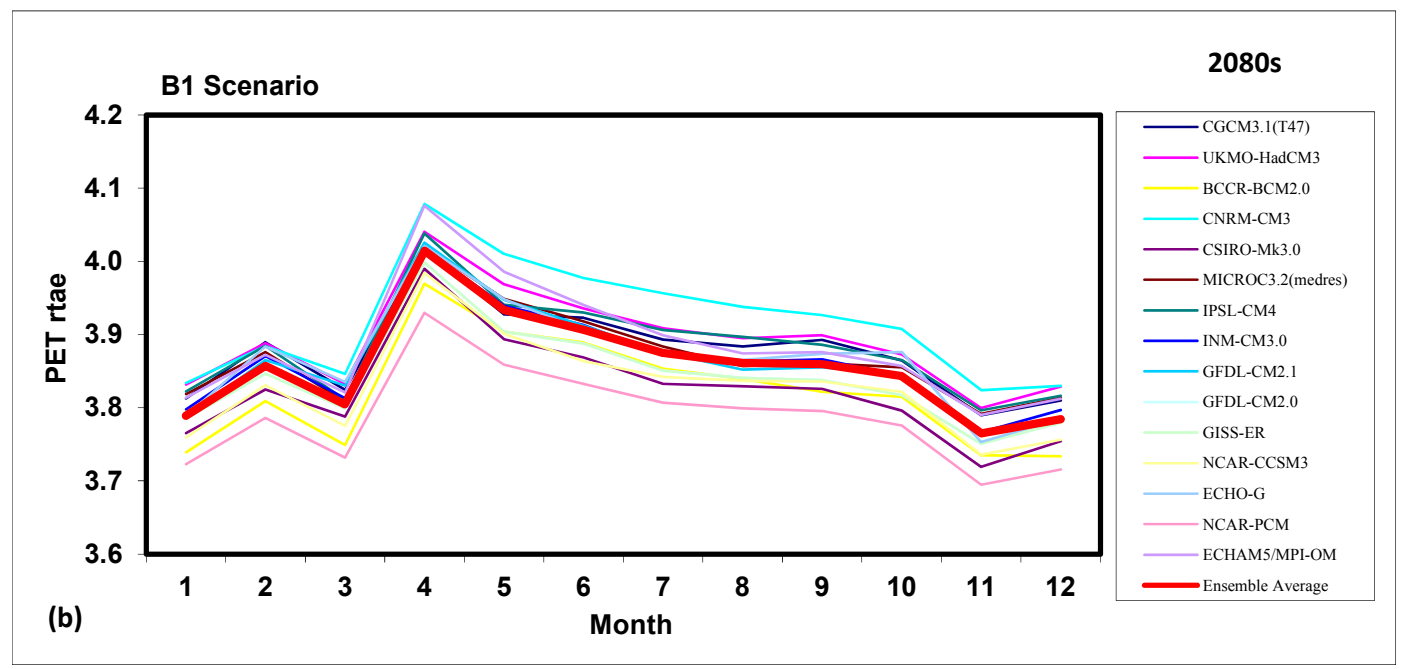

Appendix D. Table analysis for individual GCMs predictions

\begin{tabular}{lccccc}
\hline \multicolumn{5}{c}{ A2 Scenario 2020s } \\
\hline GCMs Mdels & Rpred_monthly & Obs & Rdev & Percentage Change & Remark \\
\hline CGCM3.1(T47) & 12.1 & 12.05 & 0.05 & 0.44 & Increase \\
UKMO-HadCM3 & 12.08 & 12.05 & 0.03 & 0.26 & Increase \\
BCCR-BCM2.0 & 12.1 & 12.05 & 0.06 & 0.47 & Increase \\
CNRM-CM3 & 11.31 & 12.05 & -0.74 & -6.52 & Decrease \\
CSIRO-Mk3.0 & 11.82 & 12.05 & -0.23 & -1.95 & Decrease \\
MICROC3.2(medres) & 12.2 & 12.05 & 0.16 & 1.3 & Increase \\
IPSL-CM4 & 11.78 & 12.05 & -0.26 & -2.22 & Decrease \\
INM-CM3.0 & 11.47 & 12.05 & -0.57 & -4.99 & Decrease \\
GFDL-CM2.1 & 12.11 & 12.05 & 0.07 & 0.55 & Increase \\
GFDL-CM2.0 & 12.03 & 12.05 & -0.02 & -0.16 & Decrease \\
GISS-ER & 11.95 & 12.05 & -0.1 & -0.8 & Decrease \\
NCAR-CCSM3 & 12.01 & 12.05 & -0.03 & -0.26 & Decrease \\
ECHO-G & 12.13 & 12.05 & 0.08 & 0.68 & Increase \\
NCAR-PCM & 11.82 & 12.05 & -0.23 & -1.94 & Decrease \\
ECHAM5/MPI-OM & 11.91 & 12.05 & -0.14 & -1.15 & Decrease \\
Ensemble & 11.92 & 12.05 & -0.12 & -1.04 & Decrease \\
\hline ObsVEd RdV
\end{tabular}

Obs: Observed Rdev: recharge deviation.

\section{A2 Scenario 2080s}

\begin{tabular}{lccccl}
\hline GCMs Model & Rpred_monthly & Obs & Rdev & Percentage change & Remark \\
\hline CGCM3.1(T47) & 13.07 & 12.05 & 1.02 & 8 & Increase \\
UKMO-HadCM3 & 12.84 & 12.05 & 0.79 & 6 & Increase \\
BCCR-BCM2.0 & 13.17 & 12.05 & 1.13 & 9 & Increase \\
CNRM-CM3 & 12.33 & 12.05 & 0.29 & 2 & Increase \\
CSIRO-Mk3.0 & 12.24 & 12.05 & 0.19 & 2 & Increase \\
MICROC3.2(medres) & 15 & 12.05 & 2.95 & 20 & Increase
\end{tabular}




\begin{tabular}{lccccc} 
IPSL-CM4 & 12.31 & 12.05 & 0.26 & 2 & Increase \\
INM-CM3.0 & 12.02 & 12.05 & -0.03 & 0 & Increase \\
GFDL-CM2.1 & 12.56 & 12.05 & 0.52 & 4 & Increase \\
GFDL-CM2.0 & 12.99 & 12.05 & 0.95 & 7 & Increase \\
GISS-ER & 14.98 & 12.05 & 2.93 & 20 & Increase \\
NCAR-CCSM3 & 14.13 & 12.05 & 2.08 & 15 & Increase \\
ECHO-G & 13.35 & 12.05 & 1.31 & 10 & Increase \\
NCAR-PCM & 12.6 & 12.05 & 0.55 & 4 & Increase \\
ECHAM5/MPI-OM & 14.3 & 12.05 & 2.26 & 16 & Increase \\
Ensenble average & 13.19 & 12.05 & 1.15 & 9 & Increase \\
\hline
\end{tabular}

\begin{tabular}{lccccl}
\hline \multicolumn{5}{c}{ A1B Scenario 2080s } \\
\hline CGCM3.1(T47) & Rpred_monthly & Obs & Rdev & Percentage change & Remark \\
\hline UKMO-HadCM3 & 12.58 & 12.05 & 0.54 & 4 & Increase \\
BCCR-BCM2.0 & 13.24 & 12.05 & 1.19 & 10 & Increase \\
CNRM-CM3 & 12.76 & 12.05 & 0.72 & 6 & Increase \\
CSIRO-Mk3.0 & 12.39 & 12.05 & 0.34 & 3 & Increase \\
MICROC3.2(medres) & 12.33 & 12.05 & 0.28 & 2 & Increase \\
IPSL-CM4 & 15.47 & 12.05 & 3.43 & 28 & Increase \\
INM-CM3.0 & 12.75 & 12.05 & 0.7 & 6 & Increase \\
GFDL-CM2.1 & 13.21 & 12.05 & 1.16 & 10 & Increase \\
GFDL-CM2.0 & 12.51 & 12.05 & 0.47 & 4 & Increase \\
GISS-ER & 12.56 & 12.05 & 0.51 & 4 & Increase \\
NCAR-CCSM3 & 14.8 & 12.05 & 2.75 & 23 & Increase \\
ECHO-G & 13.78 & 12.05 & 1.74 & 14 & Increase \\
NCAR-PCM & 13.38 & 12.05 & 1.34 & 11 & Increase \\
ECHAM5/MPI-OM & 12.51 & 12.05 & 0.47 & 4 & Increase \\
Ensemble average & 14.09 & 12.05 & 2.04 & 17 & Increase \\
\hline
\end{tabular}

\section{B1 Scenario}

2020s

\begin{tabular}{cccccl}
\hline GCMs Model & Rpred_monthly & Obs & Rdev & Percentage Change & Remark \\
\hline CGCM3.1(T47) & 12.08 & 12.05 & 0.03 & 0.3 & Increase \\
UKMO-HadCM3 & 12.4 & 12.05 & 0.35 & 2.8 & Increase \\
BCCR-BCM2.0 & 12.09 & 12.05 & 0.04 & 0.3 & Increase \\
CNRM-CM3 & 11.8 & 12.05 & -0.25 & -2.1 & Decrease \\
CSIRO-Mk3.0 & 11.88 & 12.05 & -0.16 & -1.4 & Decrease \\
MICROC3.2(medres) & 12.13 & 12.05 & 0.09 & 0.7 & Increase \\
IPSL-CM4 & 11.97 & 12.05 & -0.08 & -0.7 & Decrease \\
INM-CM3.0 & 11.89 & 12.05 & -0.16 & -1.3 & Decrease
\end{tabular}




\begin{tabular}{cccccc} 
GFDL-CM2.1 & 12.36 & 12.05 & 0.32 & 2.6 & Decrease \\
GFDL-CM2.0 & 11.5 & 12.05 & -0.54 & -4.7 & Decrease \\
GISS-ER & 12.39 & 12.05 & 0.35 & 2.8 & Increase \\
NCAR-CCSM3 & 12.43 & 12.05 & 0.38 & 3.1 & Increase \\
ECHO-G & 12.13 & 12.05 & 0.09 & 0.7 & Increase \\
NCAR-PCM & 11.49 & 12.05 & -0.56 & -4.9 & Decrease \\
ECHAM5/MPI-OM & 12.39 & 12.05 & 0.34 & 2.8 & Increase \\
Ensemble & 12.06 & 12.05 & 0.02 & 0.1 & Increase \\
\hline
\end{tabular}

\section{B1 Scenario 2080s}

\begin{tabular}{cccccl}
\hline GCMs Model & Rpred_monthly & Obs & Rdev & Percentage change & Remark \\
\hline CGCM3.1(T47) & 13.21 & 12.05 & 1.16 & 9 & Increase \\
UKMO-HadCM3 & 13.67 & 12.05 & 1.63 & 12 & Increase \\
BCCR-BCM2.0 & 12.66 & 12.05 & 0.62 & 5 & Increase \\
CNRM-CM3 & 12.32 & 12.05 & 0.27 & 2 & Increase \\
CSIRO-Mk3.0 & 12.29 & 12.05 & 0.25 & 2 & Increase \\
MICROC3.2(medres) & 14.43 & 12.05 & 2.39 & 17 & Increase \\
IPSL-CM4 & 12.67 & 12.05 & 0.62 & 5 & Increase \\
INM-CM3.0 & 12.18 & 12.05 & 0.13 & 1 & Increase \\
GFDL-CM2.1 & 12.51 & 12.05 & 0.46 & 4 & Increase \\
GFDL-CM2.0 & 12.88 & 12.05 & 0.83 & 6 & Increase \\
GISS-ER & 13.11 & 12.05 & 1.06 & 8 & Increase \\
NCAR-CCSM3 & 13.25 & 12.05 & 1.2 & 9 & Increase \\
ECHO-G & 13.12 & 12.05 & 1.07 & 8 & Increase \\
NCAR-PCM & 12.25 & 12.05 & 0.21 & 2 & Increase \\
ECHAM5/MPI-OM & 13.91 & 12.05 & 1.87 & 13 & Increase \\
Ensemble average & 12.96 & 12.05 & 0.92 & 7 & Increase \\
\hline
\end{tabular}

